\title{
A musealização do setor elétrico em São Paulo: construção de perspectivas para as usinas hidrelétricas
}

Dossier ElETromemoria: PAisAgem E HistóRIA

\section{Marília Xavier Cury}

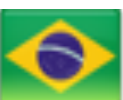

Museóloga. Mestre e Doutora em Ciências da Comunicação pela Universidade de São Paulo. Docente em

Museologia, Museu de Arqueologia e Etnologia da Universidade de São Paulo. São Paulo [SP] Brasil.

<maxavier@usp.br>.

\section{Mirian Midori Peres Yagui}

Mestre em Museologia pela Universidade de São Paulo. Técnica da Unidade de Preservação do Patrimônio Museológico da Secretaria da Cultura do Estado de São Paulo. São Paulo [SP] Brasil.

$<$ mirianmidori@gmail.com>.

\section{Resumo}

A preservação do patrimônio industrial mobiliza a Europa e Estados Unidos após 1950. 0 Brasil sofre essa influência, há setores profissionais e acadêmicos atentos à questão, entretanto com menos realizações efetivas devido a deficiências na legislação e políticas públicas para a preservação do patrimônio material. Internacionalmente a preservação ocorre com mais ênfase e a valorização decorre da demanda para um uso público do patrimônio in situ. No presente artigo, apresentam-se iniciativas de preservação e musealização do patrimônio industrial do setor elétrico e proposições que discorrem sobre o potencial de musealização das usinas hidrelétricas criadas entre 1890 e 1960 em São Paulo, como contribuição às discussões para intervir nas políticas preservacionistas e museais. Como resultado parcial do eixo Musealização do projeto Eletromemória, abordam-se questões referentes a coleções museológicas em cidades nas cercanias das usinas estudadas, a reflexão sobre a Rede Museu da Energia e apresenta-se um exercício sobre a musealidade das usinas, para a problematização de um espectro patrimonial tão relevante e complexo, mas tão pouco considerado até o momento.

\section{Palavras-chave}

Nova Museologia, musealização do setor elétrico, museus paulistas, museus da energia, comunicação museal, valorização do patrimônio industrial.

\section{The musealization of the electricity industry in São Paulo: envisaging for hydroelectric power plants}

\begin{abstract}
The preservation of industrial heritage has mobilized Europe and the United States since 1950. Brazil has been influenced by this trend, and some professional and academic segments have been alert to the issue of preservation. However, their actual achievements have been fewer than those in the Northern Hemisphere due to poor legislation and public policies focused on preserving material heritage. Worldwide, preservation is more intense and the valuing of preservation is caused by the demand for a public use of the in situ heritage. This article shows some initiatives aimed at the preservation and musealization of the power utilities' industrial heritage and proposals about the potential for the musealization of the hydroelectric power plants built between 1890 and 1960 in São Paulo, as a contribution to discussions to interfere in preservation and museum policies. As a partial result of the Musealization axis of the Electromemory project, this article addresses issues relating to museum collections in cities located in the vicinities of the targeted power plants, as well as reflexions about the Energy Museum Network. This article also formulates a hypothesis about the museality of power plants in order to raise the problem of a heritage that is so complex and relevant and yet has been poorly considered so far.
\end{abstract}

\section{Keywords}

New Museology, musealization of the power plant corporations, museums in the state of São Paulo, energy museums, museum communication, valuing of industrial heritage. 


\section{Introdução}

Os processos de musealização e patrimonialização são formas culturais distintas de preservação, muito embora estejam integradas ou entrelaçadas (LIMA, 2013; LIMA, 2014). Para resumir à mínima possibilidade, a musealização torna-se também patrimonialização, pois eleva o bem comum, preserva-o, difunde-o e o salvaguarda para finalidades contemporâneas e para as futuras gerações. Patrimonializar pela musealização requer ações outras, pois vincula a preservação a uma instituição específica - e insubstituível, porque nenhuma outra cobre plenamente o seu papel -, o museu, e a procedimentos próprios, a curadoria.

Vamos particularizar na musealização, como forma de preservação do patrimônio do setor elétrico, tendo como contexto o estado de São Paulo, as pequenas centrais hidrelétricas (PCH) e algumas das usinas hidrelétricas (UHE) criadas entre 1890 e 1960, recorte temático e temporal estabelecido pelo projeto de pesquisa Eletromemória ${ }^{1}$. Nesse recorte, surpreende a quantidade de usinas desse período ainda existentes, tendo sido escolhidas cerca de $60^{2}$, e o recuo temporal que coincide com determinado momento de expansão e desenvolvimento do estado (MORTATI; ARGOLLO FERRÃO, 2012). Pela importância das mesmas e das regiões economicamente favoráveis onde se localizam, surpreende ainda o pouco impacto nos processos museológicos dos museus municipais, muitos deles estaduais antes da municipalização de seus acervos. Ao contrário dos resultados da pesquisa "Valorização do patrimônio científico e tecnológico brasileiro" (coordenação de Marcus Granato), que apresenta papel destacado aos museus para a preservação do patrimônio de C\&T, ainda há muito pouco do patrimônio do setor elétrico em museus paulistas. Por outro lado, ainda há pouca atenção à musealização do setor elétrico, o exemplo que temos vem da Rede Museu da Energia da Fundação Energia e Saneamento de São Paulo. Podemos buscar ponderações para tal ausência.

A legislação brasileira para a proteção do patrimônio de setores específicos - como o de ciência e tecnologia (C\&T), no qual enquadraremos o setor elétrico mesmo que momentânea, parcial e restritamente - ainda é falha. Tomá-la-emos como referência, no entanto, pela ausência de legislação específica para o patrimônio industrial, categoria que melhor enquadraria o patrimônio do setor elétrico. A Constituição de 1988 ainda não especifica a proteção do patrimônio da C\&T, restringindo-se à Seção de Cultura. Há a necessidade de especificidades (GRANATO et al., 2013), pois os órgãos que detêm o patrimônio de C\&T, e estendendo para o do setor elétrico, não se entendem ou não são regulados como "culturais". Já a Lei no. 9.605 de 12 de fevereiro de 1998 "estabelece como crime contra o patrimônio cultural, o ato de destruir, inutilizar ou deteriorar instalações científicas, abrangendo, portanto, o patrimônio cultural imóvel de C\&T" (GRANATO et al., 2013, p.4, grifo nosso), legislação que não atende ao setor elétrico em pauta, a não ser que num exercício interpretativo consideremos as edificações das pequenas usinas hidrelétricas. 0 Decreto no. 3.166 de 14 de setembro de 1999, por sua vez, que se apoia na Convenção da Unidroid, Roma 1995, contribui com a conceituação de bens culturais como "aqueles bens com importância para a história ou a ciência, inclusive à história das ciências e da técnica, além de manuscritos raros e iconografia, livros antigos, documentos e publicações de interesse científico, isolados ou em coleções" (GRANATO et al., 2013, p.4). Ainda, de acordo com Marcus Granato (et al., 2013), o Brasil ratifica a Convenção Relativa à Proteção do Patrimônio Mundial, Cultural e Natural, Paris 1972, por meio do Decreto no. 80.978 de 1977. Assim, não há legislação mais ampla e sólida que vislumbre patrimônios específicos, incluindo nesses o que compreende as PCH em toda a sua materialidade e imaterialidade.

No que se refere às políticas públicas, há de se considerar aquelas voltadas à C\&T, o quanto intervêm na ideia de patrimônio científico e tecnológico e na sua musealização. Tomamos como base as políticas federais. No período de 1980-1985, o Ministério do Planejamento e Coordenação Geral

\footnotetext{
${ }^{1}$ Projeto temático financiado pela Fapesp, intitulado História da Energia Elétrica no Estado de S. Paulo (1890-1960): Patrimônio Industrial, Paisagem e Meio-Ambiente, sob coordenação de Gildo Magalhães e com a participação de pesquisadores da USP, Unesp e Unicamp.

${ }^{2}$ Segundo Mortati; Argollo Ferrão (2012, p. 680), entre 1890 e 1930 surgiram 118 centrais hidrelétricas no estado de São Paulo.
}

CURY, M.X.; YAGUI, M.M.P. A musealização do setor elétrico em São Paulo: construção de perspectivas para as 
elabora os Planos Básicos de Desenvolvimento Científico e Tecnológico (PBDCT). No terceiro Plano, segundo Handfas e Valente, "é possível localizar [...] preocupações mais explícitas com a preservação e divulgação dos vestígios da memória da ciência e da tecnologia no Brasil" (2013, p. 4), priorizando a divulgação científica e tecnológica, enriquecimento cultural da população, resgate e preservação da memória cultural do país, incentivo aos museus e instituições de pesquisa voltados à preservação de coleções (idem, p. 5).

Com o fim da ditadura militar, em 1985 é criado o Ministério da Ciência e Tecnologia (MCT), posteriormente Ministério da Ciência, Tecnologia e Inovação (MCTI), um dos principais agentes da política de C\&T no Brasil (HANDFAS; VALENTE, 2013, p. 4) que se destacou como agente na formulação e coordenação de política voltada à C\&T. Dentre os Planos Plurianuais desse ministério (PPA), o referente a 1996-1999 trata especialmente do papel de museus e bibliotecas para disponibilização de informações para o grande público e apoio à gestão de informação e socialização de acervos, conhecimentos, dados e informações, como estratégia de cidadania e desenvolvimento socioeconômico (GRANATO et al., 2013, p. 6-7). Com o PPA 2000-2003, a Comissão Lundi, instituída em 2002 pela Portaria MCT no. 420, dá continuidade aos trabalhos da Comissão Tundisi de 2000, Portaria no. 137, e teve por objetivos promover a realização de um Inventário Nacional do Patrimônio Científico e Tecnológico, propor a preservação de acervos interligados a sistemas de referência, sugerir instituição responsável pela execução da política de preservação da memória da $C \& \mathrm{~T}$ e outros para fomento à preservação e disseminação da $\mathrm{C} \& \mathrm{~T}$ nacional (GRANATO et al., 2013, p. 7-8). Somente em 2003 as recomendações da Comissão Lundi foram retomadas, nesse momento pela Comissão Especial designada pela Portaria CNPq no. 116/2003. O PPA 2004-2007 teve como estratégia a "Ciência e Tecnologia para a Inclusão e Desenvolvimento Social pela ciência, tecnologia e inovação (C,T\&I)" com a meta de ampla divulgação e popularização, desviando o foco da preservação do patrimônio de C\&T. É desse período a criação da Secretaria de Ciência e Tecnologia para a Inclusão Social (Secis) e, em sua estrutura, o Departamento de Difusão e Popularização da Ciência (Depdi), com as finalidades de proposição de políticas, programas, projeto para o desenvolvimento econômico, social e regional e a difusão de conhecimento para segmentações sociais desfavorecidas, por um lado, e a elaboração de políticas e programas para a popularização da C\&T apoiando centros e museus de ciência e ampla divulgação, por outro (HANDFAS; VALENTE, 2013, p. 4-9).

Houve uma descontinuidade nas políticas públicas da C\&T, ora favorecendo a preservação (e como exemplos temos os trabalhos das Comissões Tundisi e Lundi), ora a comunicação e a inclusão social, como se as duas perspectivas fossem antagônicas. Na perspectiva do setor de museus a preservação e a comunicação são indissociáveis, a educação não formal que realiza (independente do termo com o qual é designada) deve se sustentar no patrimônio musealizado, o que a Política Nacional dos Museus não pôde e nem poderia "acertar", em se tratando da matriz que orienta as políticas federais. 0 fato é que a preservação do patrimônio da C\&T, no qual estamos inserindo o patrimônio do setor elétrico com limitações certamente, está sem a devida atenção e priorização tal qual outros setores.

Tratemos de outra referência, no plano internacional as ações de preservação, estudo e valorização industrial e elétrico são aproximadas da "arqueologia industrial", sobretudo a partir da década de 1950, período pós II Grande Guerra. No Brasil há essa abordagem, embora nem sempre esteja tão claramente exposta, posicionada ou explorada pelo campo da arqueologia. No entanto, devemos igualmente visitar a legislação nacional voltada ao patrimônio arqueológico. A luta por legislação que proteja a arqueologia no Brasil é antiga e nasce da preocupação de salvaguardar e pesquisar sítios arqueológicos pré-coloniais, dentre eles aqueles de maior visibilidade e de interesse da especulação econômica, os sambaquis. Paulo Duarte (ALCÂNTARA, 2007) foi pioneiro na luta em prol de legislação. É de 1961 a Lei Federal 3.924 que dispõe sobre monumentos arqueológicos e pré-históricos, define o controle dos sítios e inscrição no Iphan para pesquisá-los, assim como define como crime a destruição do sítio antes do seu estudo. Apesar de não fazer distinção entre sítios arqueológicos pré-coloniais e históricos, essa Lei vem sendo um instrumento de preservação arqueológica até a atualidade. É de 1986 a Legislação de licenciamento ambiental que determina o Estudo de Impacto Ambiental e Relatório de Impacto

CURY, M.X.; YAGUI, M.M.P. A musealização do setor elétrico em São Paulo: construção de perspectivas para as 
Ambiental (EIA/Rima) pela Resolução no. 01 do Conselho Nacional do Meio Ambiente (Conama) que dispõe sobre os sítios arqueológicos, com igual destaque para os pré-históricos e históricos (RODRIGUES, 2006, p. 237). Na esfera penal a Lei de Crimes Ambientais 9.605 de 12/02/1998 define delitos contra sítios arqueológicos históricos e pré-históricos e regula infrações administrativas contra o meio ambiente cultural. Atribui ao Sistema Nacional do Meio Ambiente (Sisnama) e à Capitania dos Portos a competência para lavratura de auto de infração ambiental. Com isso, o Iphan e órgãos estaduais e municipais não têm competência legal para tal (RODRIGUES, 2006, p. 238-9). A Portaria Iphan 230 de 17/12/2002 (norma infra legal), regula os princípios básicos que regem o planejamento e a práxis arqueológica no licenciamento ambiental. Institui o termo arqueologia preventiva, atenta para a salvaguarda do patrimônio e para a plataforma conceitual da disciplina, estabelece o patrimônio arqueológico como bem da União, como parte do meio ambiente cultural, apesar do bem ambiental ser difuso. A Portaria permite Licença Prévia para os trabalhos arqueológicos (que resulta no diagnóstico) e de Instalação (Programa de Resgate, Estudo e Educação Patrimonial), Guarda (pela modernização, ampliação e fortalecimento de unidades de pesquisa existentes ou criação de unidade museológica para a guarda) (MORAIS, 2006). Já a Portaria Iphan 28 de 31/01/2003, veio para suprir lacunas quanto a estudos de arqueologia preventiva junto a usinas hidrelétricas, aquelas criadas entre fins dos 1960 e meados dos 1980, para minimizar impactos negativos da perda da base finita do patrimônio arqueológico (MORAIS, 2006). Arqueologia preventiva, então, é:

Campo da Arqueologia relacionada ao licenciamento ambiental de empreendimentos que podem causar impactos sobre o patrimônio arqueológico. Empresas de Arqueologia, arqueólogos independentes e instituições públicas atuam no sentido de avaliar e propor medidas devotadas à preservação do patrimônio arqueológico em risco (ZANETTINI) ${ }^{3}$.

Em síntese, há legislação e normatizações, mas ainda não garantem a preservação do patrimônio do setor elétrico vinculado às PCH e/ou UHE, pois para serem alvo da pesquisa arqueológica histórica e industrial devem ser procuradas por pesquisadores da academia e/ou por profissionais arqueólogos envolvidos com a arqueologia preventiva. Por outro lado, a arqueologia preventiva volta-se a grandes empreendimentos, o que não vem ocorrendo nas usinas de forma destacada. A Portaria Iphan 28, por sua vez, vem permitindo um grande avanço na arqueologia pré-colonial, pois ocorre principalmente antes da construção da usina hidrelétrica e/ou após a construção, quando vestígios arqueológicos são descobertos na sua área de concessão. Por outro lado, se a legislação existe, deve ser aprimorada e associada a políticas públicas que tornem a valorização do patrimônio arqueológico e garantam a continuidade de ações. 0 fato é, sendo Bem da União, o patrimônio arqueológico pré-colonial ou histórico (e neste estaria o industrial) deve ter a sua guarda em uma instituição de pesquisa e/ou museológica, o que vem permitindo a criação de alguns museus municipais, ora com abrangência regional, em solo brasileiro, principalmente destinados à arqueologia pré-colonial. Então, esse panorama até o momento não vem de encontro às demandas do patrimônio industrial do setor elétrico, salvo poucas exceções.

Seguindo o marco do processo de redemocratização pós ditadura militar, os anos subsequentes a 1985 foram pouco significativos para a política cultural nacional. O Ministério da Cultura (MinC) foi criado, a Lei Sarney foi decretada (1986) e com esta delega-se para a iniciativa privada poder sobre a cultura e os museus. "A proposta do governo de incentivar as empresas a investirem na área da cultura associava-se à transferência para elas do poder decisório sobre utilização do dinheiro público" (SANTOS, 2011, p. 194). Extinta em 1990, a Lei Sarney foi recriada como a Lei Rouanet (n. 8313/91). Com essa iniciativa, várias grandes exposições foram realizadas no Brasil, com apoio do MinC e de empresas que buscavam visibilidade pelos eventos de grande porte que patrocinavam sobretudo nas capitais e nos grandes museus. São dos anos de 1990 exposições em museus de artistas, muitas vezes internacionais, de renome que atraiam grande público e a atenção da mídia.

\footnotetext{
${ }^{3}$ Ver em: http://www.zanettiniarqueologia.com.br/glossario.html.
} 
As décadas de 1980 e 1990 apresentam uma grande quantidade de novos museus no Brasil, talvez uma retomada do desejo da comunidade científica latente desde a década de 1950, como apontado por Valente ${ }^{4}$ (apud HANDFAS; VALENTE, 2013, p. 4-5). São vários os fatores favoráveis: fim da ditadura militar, fortalecimento dos municípios, busca de reconhecimento de identidades, incentivo à criação de museus locais dentre outras razões. Apesar das limitações de alcance (82 instituições de C\&T investigadas), essa informação se confirma pelos dados do "Estudo sobre centros e museus de ciências - Subsídios para uma política de apoio" realizado em 1999:

\begin{abstract}
As instituições compreendidas neste estudo são jovens (62,2\%) com tempo de existência de até 20 anos. Destas, 55\% encontram-se na Região Sudeste e 21,6\% na Região Sul. Os últimos 20 anos foram particularmente importantes para a criação dessas instituições: $100 \%$ das instituições do Centro-Oeste (que fazem parte deste estudo) surgiram nesse período, 72,7\% daquelas da Região Nordeste, 66,6\% da Região Sudeste, $50 \%$ do Norte e $45,8 \%$ do Sul. Apenas um terço da amostra (32,9\%) possuem idade superior a 30 anos. Chamamos a atenção para o período entre 1969 e 1978 pois apenas 3,7\% dos centros/ museus de ciência foram criados nesse espaço de tempo. (CURY, 2000, p. 12).
\end{abstract}

Em 1986 é criado, no governo de Fernando Henrique Cardoso, o Sistema Nacional de Museus, órgão vinculado ao MinC e ao Serviço do Patrimônio Histórico e Artístico Nacional (Sphan), hoje Iphan. 0 Sistema operou para a formulação de uma política pública para os museus em parceria com o setor museológico brasileiro. Nesse governo, o Programa Monumenta é criado e a política cultural volta-se para as recomendações da Unesco quanto à inclusão social, a diversidade cultural e o patrimônio imaterial. No governo de Luiz Inácio Lula da Silva foram criados em 2003 o Departamento de Museus e Centros Culturais (Demu/Iphan), substituído pelo Instituto Brasileiro de Museus (Ibram) em 2009, o Sistema Brasileiro de Museus em 2004 e o Estatuto dos Museus Brasileiros em 2006. A Política Nacional de Museus (PNM) é de 2006. A inclusão social, a cidadania, a institucionalização de memórias e a diversidade social, étnica e cultural regem a PNM até a atualidade. Com isso, de um lado, houve um impacto imenso não somente quanto à modernização dos museus brasileiros e nacionais, mas aumentou-se sobremaneira a quantidade de museus com novas ênfases e características, tais como museus comunitários, indígenas, de favelas, organizações religiosas diversas etc. De outro, não podemos dizer que não houve uma valorização do patrimônio material na política vigente, mas não podemos afirmar com ênfase o contrário. É possível afirmar que, de fato, não há nenhuma política ou ponto desta específico voltados para a preservação do patrimônio industrial in situ e/ou formação de coleções de origens industriais. 0 que vem sendo priorizado sobremaneira desde os anos de 1980 é a preservação do patrimônio imaterial, a participação e a diversidade cultural, favorecendo os setores socioeconômicos e culturais menos privilegiados anteriormente. 0 Programa Monumenta torna-se o PAC Cidades Históricas, mas algo semelhante não aconteceu para o patrimônio industrial e, nesse contexto, para o patrimônio do setor elétrico, de modo a contemplar as PCH ou UHE.

Os estados e municípios passam a seguir o modelo de legislação como forma de fomentar a cultura, utilizando parte dos impostos devidos. Em São Paulo, desde 2006, foi instituído o Programa de Ação Cultural, inicialmente conhecido como PAC e após um ano de sua existência alterado para ProAc, por meio da lei no 12.268, de 20 de fevereiro de 2006, com o objetivo de: Apoiar e patrocinar a renovação, o intercâmbio, a divulgação e a produção artística e cultural no Estado; Preservar e difundir o patrimônio cultural material e imaterial do Estado; Apoiar pesquisas e projetos de formação cultural, bem como a diversidade cultural; Apoiar e patrocinar a preservação e a expansão dos espaços de circulação da produção cultural. Esse programa estadual atua sob duas vertentes: os benefícios fiscais do ICMS e os editais. No que tange o ProAc ICMS, ocorre a dedução fiscal do ICMS (Imposto sobre Operações Relativas à Circulação de Mercadorias e sobre Prestação de Serviços de Transporte Interestadual) para as empresas patrocinadoras dos projetos aprovados. Já os editais destinam recursos diretos do Estado a atividades culturais independentes.

\footnotetext{
${ }^{4}$ Ver Maria Esther Valente, Museus de ciências e tecnologia no Brasil: uma história da museologia entre as décadas de 1950-1970, tese de doutorado defendida na Unicamp, 2009.
}

CURY, M.X.; YAGUI, M.M.P. A musealização do setor elétrico em São Paulo: construção de perspectivas para as 
O ProAc contempla segmentos como: artes plásticas, visuais e "design"; bibliotecas, arquivos e centros culturais; cinema; circo; cultura popular; dança; eventos carnavalescos e escolas de samba; "hip-hop"; literatura; museu; música; ópera; patrimônio histórico e artístico; pesquisa e documentação; teatro; vídeo. Além dessas áreas, o programa também destina recursos para bolsas de estudo para cursos de caráter cultural ou artístico, ministrados em instituições nacionais ou internacionais sem fins lucrativos; programas de rádio e de televisão com finalidades cultural, social e de prestação de serviços à comunidade; projetos especiais - primeiras obras, experimentações, pesquisas, publicações, cursos, viagens, resgate de modos tradicionais de produção, desenvolvimento de novas tecnologias para as artes e para a cultura e preservação da diversidade cultural; restauração e conservação de bens protegidos por órgão oficial de preservação; bem como para a recuperação, construção e manutenção de espaços de circulação da produção cultural no Estado (SÃO PAULO, Lei 12.268 de 20 de fevereiro de 2006).

O Programa de Ação Cultural compõe um conjunto de diretrizes para a política cultural do Estado de São Paulo estabelecida pela Secretaria da Cultura por meio de suas unidades gestoras. Especificamente a Unidade de Preservação do Patrimônio Museológico (UPPM), é a responsável pelas diretrizes da área museológica e pelos contratos de gestão de 18 museus do Estado ${ }^{5}$, subdividindo-se em duas frentes: o Grupo de Preservação do Patrimônio Museológico (GPPM) e o Sistema Estadual de Museus (Sisem).

O GPPM é responsável pelo acompanhamento dos contratos de gestão firmados com as Organizações Sociais, parceiras na gestão de seus equipamentos culturais, e recebe apoio dos comitês técnicos (Acervo, Infraestrutura e Educativo) estabelecidos pela UPPM visando ao aprimoramento técnico e fortalecimento institucional desse conjunto de 18 museus.

Com relação ao Sisem, é responsável pelo desenvolvimento de cinco linhas de ação: articulação, apoio técnico, comunicação, formação e fomento. Eventos como o Encontro Paulista de Museus e a Reunião de Representantes Regionais dos museus do estado, organizados periodicamente, compõem a linha de articulação. 0 apoio técnico ocorre por meio da assessoria técnica oferecida aos museus paulistas, bem como da elaboração de planos museológicos e realização de visitas técnicas pela equipe do Sisem, atuando em parceria com a Organização Social ACAM Portinari. A comunicação é desenvolvida através de publicações e exposições e a formação dá-se a partir de cursos de capacitação, cursos a distância, estágios técnicos, oficinas e palestras. Estão também sob responsabilidade do SISEM os editais do Programa de Ação Cultural (ProAc) da área museológica, que correspondem à linha de ação voltada ao fomento.

Apesar da ampla atuação da Secretaria da Cultura com o objetivo de preservar e difundir o patrimônio museológico dos museus paulistas, ainda consideramos necessária uma atenção maior para a preservação do setor elétrico a partir de ações de patrimonialização e musealização.

Na Europa e nos Estados Unidos, por sua vez, vêm aumentando desde o pós II Guerra Mundial a preservação de locais ora em desuso, ora em declínio acentuado, o que leva à possibilidade de preservar, restaurar, readequar. Outra das opções é, também, a preservação de uma indústria em funcionamento, 0 que lhe confere outro caráter, mas igual importância quanto ao valor patrimonial. Há organismos que, com objetivos de estudar, proteger, conservar e comunicar, valorizam o patrimônio industrial, tais como International Committee for the Conservation of Industrial Heritage (TICCIH) e o Internacional Council on Monuments and Sites (Icomos). Esses órgãos têm representações no Brasil que, igualmente, seguem documentos tais como as Cartas de Veneza (1964) e de Nizhny Tagil (2003).

As iniciativas nacionais para a preservação do patrimônio industrial ainda são poucas, menos ainda são aquelas relacionadas à musealização. Nesse contexto, as iniciativas para a preservação do patrimônio do setor elétrico nacional ainda são em menor número, sendo que o estado de São Paulo

\footnotetext{
${ }^{5}$ Museus: Casa das Rosas, Casa Guilherme de Almeida, Catavento, Museu Felícia Leirner, Museu Histórico Pedagógico Índia Vanuíre, Museu Afro Brasil, Museu Casa de Portinari, Museu da Casa Brasileira, Museu da Imagem e do Som, Museu da Língua Portuguesa, Museu de Arte Sacra, Museu do Café, Museu do Futebol, Paço das Artes, Museu da Imigração, Pinacoteca do Estado, Estação Pinacoteca e Memorial da Resistência.
}

CURY, M.X.; YAGUI, M.M.P. A musealização do setor elétrico em São Paulo: construção de perspectivas para as 
tem o bom exemplo da Rede Museu da Energia. Os setores acadêmicos, no entanto, estão atentos a discussões pertinentes, embora nem sempre consigam ver na prática os resultados pretendidos. Ainda, há que se buscar especificidades e especializações, pois musealizar uma fábrica têxtil ou uma estação ferroviária não é o mesmo que musealizar uma usina hidroelétrica, as questões são outras, seja quanto a critérios de restauro e conservação preventiva e/ou curativa, problemática conceitual e adequações para um programa de uso. Nesse sentido, este artigo que ora é apresentado tem o objetivo geral de trazer à luz do processo de preservação patrimonial do setor elétrico questões que promovam discussões em torno da musealização desse setor, partindo de uma situação específica que é o estado de São Paulo e as PCH e UHE criadas entre 1890 e 1960. Não temos o propósito de gerar orientações técnicas ou pragmáticas, para tanto, o objetivo do artigo é levantar pontos para deflagrar uma situação premente, para colaborar com políticas públicas que incentivem a preservação e valorização por meio dos museus. Cercamos a questão pelo entendimento que os museus próximos a algumas das PCH e UHE têm um papel a cumprir. Esses museus, em grande parte municipais, deveriam a prioristicamente e por definição ter o patrimônio do setor elétrico em suas agendas, em se tratando de instituições museais cuja abrangência conceitual é o próprio município. Ainda, nos interessa abordar a rede de museus da Fundação Energia e Saneamento para averiguar seus pressupostos e o estado da "arte" na atualidade. Para finalizar, fazemos um exercício para a musealização de PCH e UHE, de modo a problematizá-las e ver nelas o potencial de musealização.

A utilização da energia elétrica no país, iniciada no final do século XIX, até os dias atuais, nos faz refletir sobre questões que tangem diferentes aspectos. Historicamente, a energia elétrica está relacionada de forma intrínseca ao desenvolvimento industrial e tecnológico, a mudanças ambientais e paisagísticas e a aspectos culturais e patrimoniais, devido a isso, torna-se tão importante a preservação e comunicação do patrimônio do setor elétrico. Na atualidade, problematiza-se não apenas a relevância da energia elétrica no cotidiano da sociedade e a consequente dependência gerada, mas também a dificuldade para o suprimento de uma demanda crescente por meio da ampliação da geração e a economia de energia. Com isso, nota-se ao longo dos anos a realização de diferentes ações voltadas ao setor elétrico, com o intuito de suprir essa alta demanda por energia, como, por exemplo, a reativação de pequenas centrais hidrelétricas construídas entre o final do século XIX e início do século XX, além de ações para a preservação da história desse setor, atribuindo novos usos sociais a essas usinas hidrelétricas, transformando-as em espaços culturais e museus. É esse momento que queremos discutir e possibilitar perspectivas futuras.

\section{São Paulo: a musealização do setor elétrico}

Nos anos de 1980 o termo musealização aparece e passa a ser usado lentamente, principalmente após a metade da década. Em 1981, pioneiramente, Guarnieri já o usa em um artigo. Sua ideia era a abrangência nas ações curatoriais, partindo da coleta de acervo e demais ações que hoje denominamos como curatoriais: formação de acervo/coleção, pesquisa, conservação, documentação museológica, exposição e educação. Posteriormente, Desvallées (1998) circunscreve musealização à mudança de status de um objeto para o objeto museológico. Aproximando as duas concepções, musealização é a atribuição de um novo estatuto a um objeto, não somente selecionando-o e destacando-o de outros, mas voltando as ações a esse objeto por meio da curadoria. Mais recentemente Desvallées e Mairesse nos apresentaram uma diversidade de posições no Dicionário Enciclopédico de Museologia (2011), todas elas, em algum sentido, nos levam à ideia de que musealização é um processo, logo, às vezes usamos o termo para todas as ações de curadoria, ou para alguma ação em específico, por isso podemos não somente encontrar na bibliografia o conceito, mas usar o termo musealização para a coleta e entrada de um objeto na instituição museu ou mesmo para a concepção de uma exposição.

Curadoria, num sentido mais contemporâneo e de acordo com um ponto de vista, é a designação para todas as ações em um museu em torno do objeto museológico, assim, todas as ações que perpassam a musealização são ações curatoriais. A pesquisa certamente é mais recorrentemente reconhecida como curadoria, mas as demais: coleta, conservação, documentação, exposição e educação também fazem parte dessas ações. Mais recentemente, encontramos na bibliografia, por exemplo, a aplicação do termo como "curadoria educacional", redundância que se justifica como marco de valorização da educação em museu como ação curatorial. 
Ao nos referirmos à musealização do setor elétrico no estado de São Paulo estamos considerando as seguintes possibilidades: a presença de objetos ou coleções formadas a partir desse prisma por museus, muitas vezes municipais com recortes históricos locais, museus que se destinam a, ou compreendem essa temática, rede de instituições - museus que trabalham em associação mútua, interligados e em complementaridade - e novos museus - modelos museais que ampliam a ideia do museu clássico, considerando a musealização in situ e a "coleção" como inúmeros elementos materiais e imateriais situados ou presentes simbolicamente em dado território.

Um aspecto que gera dificuldades é referente ao momento transitório pelo qual os museus passam, tendo que rever tipologias, mas convivendo com antigos modelos (CURY, 2014). Por exemplo, o Cadastro Nacional de Museus apoia-se em tipologias de coleções que, hoje, parecem limitadas, por mais abrangentes que pretendam ser. As categorias possíveis são: Antropologia e Etnografia, Arqueologia, Artes Visuais, Ciências Naturais e História Natural, Ciência e Tecnologia, História, Imagem e Som, Virtual, Biblioteconômico, Documental e Arquivístico (IBRAM, 2011, p. 19-20). Para a categoria Ciência e Tecnologia temos: "bens culturais representativos da evolução da História da Ciência e da Técnica" (idem, p. 19). Muito embora o cadastro permita a seleção de diversas opções, é muito difícil por ele detectar a presença do patrimônio industrial e do setor elétrico nos museus brasileiros, dentre eles os paulistas, diga-se, o maior quantitativo de instituições no país. Dessa forma, dentro das categorias do Cadastro Nacional de Museus, coleções do setor elétrico oriundas de PCH e UHE teriam pouca visibilidade, embora estivessem marcadas em itens tais como Antropologia (a cultura das empresas e do trabalho), Arqueologia (industrial e histórica), Artes Visuais (desenhos e ilustrações), Ciência e Tecnologia, História (da técnica, do setor, do setor em São Paulo e do estado de São Paulo), Virtual (pelo automatismo na atualidade), Biblioteconômico (catálogos, livros e outros suportes), Documental e Arquivístico. 0 mesmo problema de levantamento de dados teve menor peso em Portugal. Segundo Mota e Sampaio (2014), o Observatório das Actividades Culturais (OAC), em estudo realizado entre 2000 e 2005, dentre o universo de 530 museus portugueses em funcionamento, apresenta que 81 deles mantinham coleções de objetos industriais, sendo que nas localidades mais industrializadas, como Lisboa, Porto e Setúbal, a presença do patrimônio industrial em museus era mais marcante.

Essa discussão, à parte da formatação de cadastros para levantamento de dados, nos leva a tipologias de acervo referente ao setor elétrico (técnico e tecnológico, científico, arqueológico, histórico, arquitetônico, industrial, empresarial, natural) e a tipologia de museus para esse patrimônio (de ciência e tecnologia, de arqueologia, de história, de indústria, de empresa, de cidade). Ainda, os museus mais recentemente podem ser vistos também a partir da abordagem que definem para si, uma perspectiva holística que transcende as áreas de conhecimento ou recortes especializados. Nesse sentido é que o patrimônio do setor elétrico deva ser entendido na sua transversalidade e, assim, outros modelos de museus são vislumbrados, associados ou não ao museu tradicional ou clássico, o que denominamos simplesmente museu à modelagem institucional que decorre da formação de um acervo abrigado em uma edificação, para nos referirmos à sua mínima formulação. A Nova Museologia nos dá suporte para novos modelos museais: ecomuseu, museu comunitário, museu integral, museu de percurso, museu de território, para citar alguns exemplos que se aproximam do exercício de musealização que nos propomos a realizar. Isto requer nesse momento algumas conceituações. $\mathrm{O}$ ecomuseu e o museu comunitário foram por muito tempo e são para alguns profissionais sinônimos. Atualmente, no entanto, há uma sutil distinção, o “'ecomuseu' passou a ser sinônimo de um tipo especial de museu comunitário, fundamentado na musealização de um território e na relação entre este território, o meio ambiente integral (entendido como patrimônio) e as comunidades que ali conviveram e/ou convivem" (SCHEINER, 2012, p. 24). Fazemos, então, uma separação entre museu comunitário - aquele que é gestado por uma segmentação social - e o ecomuseu, cuja ideia de território, patrimônio e sociedade nos interessa sobremaneira. No entanto, podemos usar simplesmente o termo museu de território, para evitar possíveis contradições ou contrarreações.

Esse tipo de patrimônio musealizado cobrindo um sítio, extensão territorial significativa, geralmente se apresenta a céu aberto, podendo incluir espaços fechados por causa da sua constituição original geográfica e cultural, ou também pelas necessidades de sua readaptação e, de modo predominante, configura o modelo Museu de Território (LIMA, 2013, p. 12).

CURY, M.X.; YAGUI, M.M.P. A musealização do setor elétrico em São Paulo: construção de perspectivas para as 
Outro termo de interesse é museu de percurso que, para Lima, é "denominação que ainda não está claramente definida e ainda merece estudos do campo museológico (2013, p. 16). Mas, para Rossi e Barbuy, trata-se de definição tipológica,

[...] expressão criada para definir sua museografia [...] [que] não consiste apenas numa forma de apresentação, num design de conotações simplesmente estéticas. A museografia, por definição, é a concretização de conceitos, não existindo, portanto, sem os vetores museológicos que a orientam (1992, p. 57).

As autoras, à época, referiram-se ao que hoje denominamos de expografia, termo introduzido no campo museal no fim da década de 1990. Dessa forma, museu-percurso (como grafado por elas) referencia literalmente um caminho conceitual pelo qual uma exposição se realiza como ideia materializada. De qualquer forma, interessa-nos a concepção de museu de percurso, pois subentende, uma vez que as autoras partem da filosofia do ecomuseu, que há uma "exposição" que se realiza pelo deslocamento das pessoas em dado território, o que permite a apreensão de um conceito por meio de dado patrimônio.

Em síntese, musealização relaciona-se à curadoria e ambas ao objeto museológico. Esse objeto integra o acervo de um museu e recebe um tratamento curatorial. Mas esse objeto mesmo que musealizado pode permanecer in situ, integrado e articulado com outros, para darem conta de determinado conceito que os une por um território. Nessa situação, os objetos museológicos estão em um território e o museu é de território. No caso do objeto museológico estar em um museu que se relaciona a outros objetos de outros museus, independente das formas museais que possuam, e/ou relacionar-se a objeto in situ, nesse caso, esses objetos fazem parte de uma estrutura de museu de percurso, pois exigem uma circulação para as devidas articulações conceituais e apreensão do que podemos, com reservas, denominar igualmente como "acervo". E, da mesma forma que um museu-casa moradia que representa uma época e/ou pessoa de relevância patrimonial - que é objeto de acervo e a própria instituição, o museu de território e o de percurso podem ser e estar em edificações ou outras estruturas arquitetônicas. Sendo assim, discorremos sobre a musealização do setor elétrico no estado de São Paulo, partindo da premissa de que as possibilidades são muitas e a variedade abrangente.

\subsection{Os museus e o patrimônio do setor elétrico}

Em São Paulo, a musealização do patrimônio do setor elétrico ocorre, mas é ainda incipiente. Num universo de oitenta e sete museus situados em municípios que possuem pequenas centrais hidrelétricas construídas entre 1890 e 1960, apenas em dezessete deles há referências do setor elétrico (YAGUI, 2014).

Essa realidade pode ser observada no Quadro 1, que relaciona as usinas, sua data de construção e início de operação, o proprietário atual, o município onde se situa e os museus existentes nessa área. A identificação dos museus situados nesses municípios baseou-se no Museus $S P$, uma lista de instituições apresentada no site do Sistema Estadual de Museus (Sisem), elaborada a partir do levantamento de museus do estado realizado no ano de 2010 por equipe especializada coordenada pela Unidade de Preservação do Patrimônio Museológico.

A pesquisa considerou também os museus situados nas cidades que sofreram emancipação, mas que no passado detiveram em seus territórios as PCH e UHE determinadas neste estudo. Essas informações deram origem ao Quadro 2, onde constam dados referentes à emancipação dos municípios.

Notou-se, a partir de uma primeira análise, que dentre as 53 cidades listadas nos Quadros 1 e 2, cerca de 20 delas não possuem ao menos um museu. Essa informação reflete a realidade do estado de São Paulo se considerarmos que dentre seus 645 municípios, apenas 190 possuem museus, sendo cadastradas no Sisem-SP 415 instituições. Dentre elas, identificamos uma grande diversidade de tipologias, se basearmos a classificação de acordo com suas coleções, tais como museus de arte, históricos, de ciência e arqueológicos. 
Quadro 1. Museus existentes nas proximidades das PCH e UHE.

\begin{tabular}{|c|c|c|c|c|}
\hline Usina & $\begin{array}{c}\text { Início } \\
\text { construção } \\
\text { (c)/ início } \\
\text { operação (op) }\end{array}$ & $\begin{array}{l}\text { Proprietário } \\
\text { atual }\end{array}$ & Município & Museus \\
\hline $\begin{array}{l}\text { PCH Capão } \\
\text { Preto }\end{array}$ & $\begin{array}{l}\text { C: } 1911 \\
\text { Op: } 1911\end{array}$ & \multirow{4}{*}{ CPFL } & \multirow{4}{*}{ São Carlos } & Museu de São Carlos \\
\hline $\begin{array}{l}\text { PCH } \\
\text { Monjolinho }\end{array}$ & $\begin{array}{l}\text { C: } 1909 \\
\text { Op: } 1909\end{array}$ & & & Museu de Pedra Tinho Leopoldino \\
\hline \multirow{2}{*}{ PCH Santana } & & & & $\begin{array}{l}\text { Museu de Computação Prof. Odelar } \\
\text { Leite Linhares }\end{array}$ \\
\hline & & & & Museu Asas de um Sonho \\
\hline \multirow{5}{*}{ PCH Chibarro } & \multirow{5}{*}{ Op: 1912} & \multirow{5}{*}{ CPFL } & \multirow{5}{*}{ Araraquara } & $\begin{array}{l}\text { Museu da Imagem e Som Maestro José } \\
\text { Tescar }\end{array}$ \\
\hline & & & & Museu de Arqueologia e Paleontologia \\
\hline & & & & Museu do Futebol e Esportes \\
\hline & & & & $\begin{array}{l}\text { Museu Ferroviário Francisco } \\
\text { Aureliano de Araújo }\end{array}$ \\
\hline & & & & $\begin{array}{l}\text { Museu Histórico e Pedagógico } \\
\text { Voluntários da Pátria }\end{array}$ \\
\hline PCH Dourados & $\begin{array}{l}\text { C: } 1926(?) \\
\text { Op: } 1926\end{array}$ & CPFL & Nuporanga & $\longrightarrow$ \\
\hline $\begin{array}{l}\mathrm{PCH} \\
\text { Americana }\end{array}$ & C: 1949 & \multirow{2}{*}{ CPFL } & \multirow{2}{*}{ Americana } & \multirow{2}{*}{ Museu de Arte Contemporânea } \\
\hline $\begin{array}{l}\mathrm{PCH} \\
\text { Cariobinha }\end{array}$ & C: 1936 & & & \\
\hline $\begin{array}{l}\text { PCH Salto de } \\
\text { Pinhal }\end{array}$ & $\begin{array}{l}\text { C: } 1911 \\
\text { Op: } 1911\end{array}$ & \multirow{3}{*}{ CPFL } & \multirow{3}{*}{$\begin{array}{l}\text { Espírito Santo } \\
\text { do Pinhal }\end{array}$} & \\
\hline $\begin{array}{l}\text { PCH Eloy } \\
\text { Chaves }\end{array}$ & & & & $\longrightarrow$ \\
\hline PCH Pinhal & $\begin{array}{l}\text { C: } 1928 \\
\text { Op: } 1928\end{array}$ & & & \\
\hline PCH Esmeril & $\begin{array}{l}\text { C: } 1911 \\
\text { Op: } 1912\end{array}$ & CPFL & $\begin{array}{l}\text { Patrocínio } \\
\text { Paulista }\end{array}$ & $\longrightarrow$ \\
\hline \multirow[t]{3}{*}{$\begin{array}{l}\text { PCH São } \\
\text { Joaquim }\end{array}$} & $\begin{array}{l}\text { C: } 1911 \\
\text { Op: } 1911\end{array}$ & CPFL & Guará & - \\
\hline & & & & Casa do Café \\
\hline & & & & Museu Universitário \\
\hline
\end{tabular}




\begin{tabular}{|c|c|c|c|c|}
\hline \multirow{15}{*}{$\begin{array}{l}\text { PCH Salto } \\
\text { Grande }\end{array}$} & \multirow{15}{*}{$\begin{array}{l}\text { C: } 1912 \\
\text { Op: } 1912\end{array}$} & \multirow{15}{*}{ CPFL } & \multirow{15}{*}{ Campinas } & $\begin{array}{l}\text { Museu Presbiteriano Julio Andrade } \\
\text { Ferreira }\end{array}$ \\
\hline & & & & Museu Histórico Ambiental Casarão \\
\hline & & & & Museu Exploratório de Ciências \\
\hline & & & & $\begin{array}{l}\text { Museu Dinâmico de Ciências de } \\
\text { Campinas }\end{array}$ \\
\hline & & & & Museu Dinâmico Viação Férrea \\
\hline & & & & Museu do Instituto Penido Burnier \\
\hline & & & & Museu do Café \\
\hline & & & & Museu Arquidiocesano de Campinas \\
\hline & & & & Museu da Imagem e do Som \\
\hline & & & & Museu da Cidade \\
\hline & & & & Museu Carlos Gomes \\
\hline & & & & Museu Campos Salles \\
\hline & & & & $\begin{array}{l}\text { Museu de Arte Contemporânea de } \\
\text { Campinas José Pancetti }\end{array}$ \\
\hline & & & & Museu de História Natural \\
\hline & & & & $\begin{array}{l}\text { Museu de Zoologia Professor Adão } \\
\text { José Cardoso }\end{array}$ \\
\hline $\begin{array}{l}\text { PCH Gavião } \\
\text { Peixoto }\end{array}$ & Op: 1913 & CPFL & Gavião Peixoto & - \\
\hline PCH Lençóis & $\begin{array}{l}\text { C: } 1917(?) \\
\text { Op: } 1917\end{array}$ & CPFL & Macatuba & \\
\hline PCH Jaguari & $\begin{array}{l}\text { C: } 1917 \\
\text { Op: } 1919\end{array}$ & CPFL & Pedreira & Museu Histórico da Porcelana \\
\hline PCH Buritis & Op: 1922 & CPFL & Buritizal & $\longrightarrow$ \\
\hline $\begin{array}{l}\text { PCH Três } \\
\text { Saltos }\end{array}$ & $\begin{array}{l}\text { C: } 1928(?) \\
\text { Op: } 1928\end{array}$ & CPFL & Torrinha & $\longrightarrow$ \\
\hline PCH Socorro & $\begin{array}{l}\text { C: } 1909 \\
\text { Op: } 1909\end{array}$ & CPFL & Socorro & $\begin{array}{l}\text { Museu Histórico Municipal Dr. João } \\
\text { Batista Gomes Ferraz }\end{array}$ \\
\hline PCH Rio Novo & $\begin{array}{l}\text { C: } 1909 \\
\text { Op: } 1909\end{array}$ & CLFSC & & Museu Histórico e Pedagógico Anita \\
\hline $\begin{array}{l}\text { PCH Santa } \\
\text { Helena }\end{array}$ & $\begin{array}{l}\text { C: } 1935(?) \\
\text { Op: } 1938\end{array}$ & Outras & & Ferreira de Maria \\
\hline PCH Boa Vista & Op: 1913 & CPFL CLFSC & Sarutaiá & $\underline{-}$ \\
\hline
\end{tabular}




\begin{tabular}{|c|c|c|c|c|}
\hline $\begin{array}{l}\text { PCH } \\
\text { Paranapanema } \\
\text { me }\end{array}$ & $\begin{array}{l}\text { C: } 1934 \\
\text { (barragem) } \\
\text { Op: } 1957\end{array}$ & \multirow{3}{*}{ CPFL CLFSC } & \multirow{3}{*}{ Piraju } & \multirow{2}{*}{ Museu Histórico Constantino Leman } \\
\hline $\begin{array}{l}\mathrm{PCH} \\
\text { Paranapanema } \\
\text { md }\end{array}$ & $\begin{array}{l}\text { C: } 1934 \\
\text { (obras da } \\
\text { barragem) } \\
\text { Op: } 1988\end{array}$ & & & \\
\hline $\begin{array}{l}\text { PCH } \\
\text { Paranapanema } \\
\text { Nova }\end{array}$ & $\begin{array}{l}1934 \text { (obras } \\
\text { da barragem) } \\
\text { Op: } 1999\end{array}$ & & & $\begin{array}{l}\text { Centro Regional de Arqueologia } \\
\text { Ambiental, MAE - USP }\end{array}$ \\
\hline PCH Lavrinha & Op: 1947 & CPFL CSPE & $\begin{array}{l}\text { São Miguel } \\
\text { Arcanjo }\end{array}$ & - \\
\hline PCH Bocaina & Op: 1912 & EMAE & $\begin{array}{l}\text { Cachoeira } \\
\text { Paulista }\end{array}$ & Museu Dr. Costa Junior \\
\hline \multirow[b]{2}{*}{ PCH Sodré } & \multirow{2}{*}{$\begin{array}{l}\text { C: } 1912 \\
\text { Op: } 1912\end{array}$} & \multirow[b]{2}{*}{ EMAE } & \multirow[b]{2}{*}{ Guaratinguetá } & Museu Frei Galvão \\
\hline & & & & $\begin{array}{l}\text { Museu Histórico e Pedagógico } \\
\text { Conselheiro Rodrigues Alves }\end{array}$ \\
\hline PCH Isabel & Op: 1915 & EMAE & $\begin{array}{l}\text { Pindamo - } \\
\text { nhangaba }\end{array}$ & $\begin{array}{l}\text { Museu Histórico e Pedagógico Dom } \\
\text { Pedro I e Dona Leopoldina }\end{array}$ \\
\hline PCH Rasgão & Op: 1925 & EMAE & $\begin{array}{l}\text { Pirapora do } \\
\text { Bom Jesus }\end{array}$ & Museu São Norberto \\
\hline \multirow{2}{*}{$\begin{array}{l}\text { PCH Porto } \\
\text { Góes }\end{array}$} & \multirow{2}{*}{ Op: 1928} & \multirow{2}{*}{ EMAE } & \multirow{2}{*}{ Salto } & Memorial do Rio Tietê \\
\hline & & & & Museu da Cidade de Salto \\
\hline $\begin{array}{l}\text { UHE Henry } \\
\text { Borden }\end{array}$ & C: 1926 & EMAE & Cubatão & $\longrightarrow$ \\
\hline \multirow{3}{*}{$\begin{array}{l}\text { PCH } \\
\text { Corumbataí }\end{array}$} & \multirow{3}{*}{$\begin{array}{l}\text { C: } 1892 \\
\text { Op: } 1895\end{array}$} & \multirow{3}{*}{$\begin{array}{l}\text { Fund. } \\
\text { Energia e } \\
\text { Saneamento }\end{array}$} & \multirow{3}{*}{ Rio Claro } & Museu da Energia de Rio Claro \\
\hline & & & & Museu do Eucalipto \\
\hline & & & & $\begin{array}{l}\text { Museu Histórico e Pedagógico Amador } \\
\text { Bueno da Veiga }\end{array}$ \\
\hline \multirow{2}{*}{$\begin{array}{l}\text { PCH São } \\
\text { Valentim }\end{array}$} & \multirow{2}{*}{$\begin{array}{l}\text { C: } 1910 \\
\text { Op: } 1911\end{array}$} & \multirow{2}{*}{$\begin{array}{l}\text { Fund. } \\
\text { Energia e } \\
\text { Saneamento }\end{array}$} & \multirow{2}{*}{$\begin{array}{l}\text { Santa Rita do } \\
\text { Passa Quatro }\end{array}$} & Usina-Parque de São Valentim \\
\hline & & & & $\begin{array}{l}\text { Museu Histórico e Pedagógico } \\
\text { Zequinha de Abreu }\end{array}$ \\
\hline $\begin{array}{l}\mathrm{PCH} \\
\text { Salesópolis }\end{array}$ & $\begin{array}{l}\text { C: } 1912 \\
\text { Op: } 1914\end{array}$ & $\begin{array}{l}\text { Fund. } \\
\text { Energia e } \\
\text { Saneamento }\end{array}$ & Salesópolis & Museu da Energia de Salesópolis \\
\hline \multirow[b]{2}{*}{ PCH Jacaré } & \multirow[b]{2}{*}{1929} & \multirow{2}{*}{$\begin{array}{l}\text { Fund. } \\
\text { Energia e } \\
\text { Saneamento }\end{array}$} & \multirow[b]{2}{*}{ Brotas } & Museu do Cotidiano \\
\hline & & & & Usina-Parque do Jacaré \\
\hline $\begin{array}{l}\text { PCH JBL } \\
\text { Figueiredo }\end{array}$ & $\begin{array}{l}\text { C: } 1949(?) \\
\text { Op: } 1952\end{array}$ & Fund. & & Casa de Cultura Euclides da Cunha \\
\hline
\end{tabular}




\begin{tabular}{|c|c|c|c|c|}
\hline $\begin{array}{l}\text { PCH Santa } \\
\text { Alice }\end{array}$ & Op: 1907 & \multirow[t]{2}{*}{$\begin{array}{l}\text { Energia e } \\
\text { Saneamento } \\
\text { Outras }\end{array}$} & \multirow[t]{2}{*}{$\begin{array}{l}\text { São José do } \\
\text { Rio Pardo }\end{array}$} & \multirow{2}{*}{ Museu Riopardense } \\
\hline $\begin{array}{l}\text { PCH Rio do } \\
\text { Peixe }\end{array}$ & Op: 1925 & & & \\
\hline PCH Fojo & $\begin{array}{l}\text { C: } 1930 \\
\text { Op: } 1930\end{array}$ & \multirow{3}{*}{ Outras } & \multirow{3}{*}{$\begin{array}{l}\text { Campos do } \\
\text { Jordão }\end{array}$} & Museu Casa de Xilogravura \\
\hline $\begin{array}{l}\text { PCH Marmelos } \\
\text { I }\end{array}$ & Op: 1937 & & & \multirow{2}{*}{ Museu Felícia Leirner } \\
\hline $\begin{array}{l}\text { PCH Marmelos } \\
\text { II }\end{array}$ & Op:1910 & & & \\
\hline PCH Batista & Op: 1913 & \multirow{2}{*}{ Outras } & \multirow{2}{*}{ Pilar do Sul } & \\
\hline PCH Pilar & Op: 1928 & & & - \\
\hline $\begin{array}{l}\text { PCH } \\
\text { Votorantim }\end{array}$ & $\begin{array}{l}\text { C: } 1912(?) \\
\text { Op: } 1940\end{array}$ & \multirow{2}{*}{$\begin{array}{l}\text { Votorantim } \\
\text { Energia }\end{array}$} & \multirow{2}{*}{ Votorantim } & \multirow{2}{*}{ Museu Municipal de Votorantim } \\
\hline $\begin{array}{l}\text { UHE } \\
\text { Itupararanga }\end{array}$ & $\begin{array}{l}\text { C: } 1911 \\
\text { Op: } 1914\end{array}$ & & & \\
\hline PCH Jurupará & Op: 1947 & $\begin{array}{l}\text { Votorantim } \\
\text { Energia }\end{array}$ & Piedade & $\longrightarrow$ \\
\hline PCH Quatiara & $\begin{array}{l}\text { C: } 1938 \\
\text { Op: } 1939\end{array}$ & $\begin{array}{l}\text { Votorantim } \\
\text { Energia }\end{array}$ & Rancharia & $\longrightarrow$ \\
\hline $\begin{array}{l}\text { PCH Laranja } \\
\text { Doce }\end{array}$ & $\begin{array}{l}\text { C: } 1928 \\
\text { Op: } 1929\end{array}$ & $\begin{array}{l}\text { Votorantim } \\
\text { Energia }\end{array}$ & Martinópolis & Museu da FEPASA \\
\hline PCH Itatinga & $\begin{array}{l}\text { C: } 1906 \\
\text { Op: } 1910\end{array}$ & Outras & Bertioga & Forte São João \\
\hline PCH Ester & $\begin{array}{l}\text { C: } 1930(?) \\
\text { Op: } 1930\end{array}$ & Outras & Cosmópolis & - \\
\hline \multirow{5}{*}{ PCH Boyes } & \multirow{5}{*}{$\begin{array}{l}\text { C: } 1938(?) \\
\text { Op: } 1938\end{array}$} & \multirow{5}{*}{ Outras } & \multirow{5}{*}{ Piracicaba } & $\begin{array}{l}\text { Museu da Água Francisco Salgot } \\
\text { Castillon }\end{array}$ \\
\hline & & & & $\begin{array}{l}\text { Museu e Centro de Ciências, Educação } \\
\text { e Artes Luiz de Queiroz }\end{array}$ \\
\hline & & & & $\begin{array}{l}\text { Museu Histórico e Pedagógico } \\
\text { Prudente de Moraes }\end{array}$ \\
\hline & & & & $\begin{array}{l}\text { Museu Odontológico Dr. Grace Harriet } \\
\text { Clark Alvarez }\end{array}$ \\
\hline & & & & Museu Professor Jair de Araújo Lopes \\
\hline PCH Cajuru & Op: 1924 & Outras & Cajuru & - \\
\hline PCH Itaipava & Op: 1914 & Outras & $\begin{array}{l}\text { Santa Rosa do } \\
\text { Viterbo }\end{array}$ & $\longrightarrow$ \\
\hline
\end{tabular}




\begin{tabular}{|c|c|c|c|c|}
\hline PCH Santa Fé & Op: 1929 & Outras & Nova Europa & 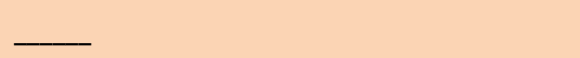 \\
\hline \multirow{2}{*}{$\begin{array}{l}\text { PCH Reinaldo } \\
\text { Gonçalves }\end{array}$} & \multirow{2}{*}{ Op: 1924} & \multirow{2}{*}{ Outras } & \multirow{2}{*}{ Itápolis } & $\begin{array}{l}\text { Memorial Maçônico Comendador } \\
\text { Romeu Bonini }\end{array}$ \\
\hline & & & & $\begin{array}{l}\text { Museu Histórico e Pedagógico } \\
\text { Alexandre de Gusmão }\end{array}$ \\
\hline \multirow{2}{*}{$\begin{array}{l}\text { Salto } \\
\text { Avanhandava }\end{array}$} & & \multirow{2}{*}{ Outras } & \multirow{2}{*}{ Penápolis } & $\begin{array}{l}\text { Museu Histórico e Pedagógico Gláucia } \\
\text { Castilho Brandão }\end{array}$ \\
\hline & & & & Museu Municipal do Folclore \\
\hline $\begin{array}{l}\text { PCH Pary- } \\
\text { veado }\end{array}$ & $\begin{array}{l}\text { C: } 1934 \\
\text { Op: } 1937\end{array}$ & Outras & Cândido Mota & $\longrightarrow$ \\
\hline
\end{tabular}

Fonte: Yagui, 2014.

Após efetuar o recorte da lista, a partir da escolha dos museus com base nas características do acervo, realizou-se o contato com as instituições museológicas, consultando-as sobre a composição de seus acervos com base na relação de objetos-testemunhos do processo brasileiro de industrialização listados por Guarnieri (1980) em sua tese de doutorado, mas com algumas adaptações:

a) Máquinas utilizadas nas usinas e em suas dependências administrativas e de ação social;

b) Catálogos, desenhos, projetos, marcas e patentes de objetos industriais do setor energético;

c) Cartazes, folhetos, almanaques e qualquer outro material de divulgação e propaganda da usina;

d) Registros e documentos, inclusive fotográficos, das classes empresarial e operária, incluindo publicações especializadas sobre a usina;

e) Registros referentes às condições de vida das personagens envolvidas no processo de construção, manutenção e gestão da usina;

f) Registros das atividades de distribuição de energia e seu comércio, compreendendo a preservação de documentação, material de propaganda e divulgação, etc;

g) Registros filmográficos, fílmicos e sonoros desses objetos e locais, assim como coleta de depoimentos de trabalhadores da usina;

h) 0 registro das técnicas nacionais primitivas, das técnicas assimiladas e da tecnologia criada, com ênfase, na atual conjuntura, das tecnologias alternativas;

i) Modelos e representações, estáticos ou animados, documentadores das atividades de produção, distribuição e consumo de energia etc. (YAGUI, 2014, p.77).

Essa relação constituiu-se apenas como um roteiro preliminar e não esgotou as possibilidades de identificação de outros objetos que não estivessem contemplados nessa listagem, como os eletrificados utilizados no cotidiano da sociedade e ferramentas de trabalho empregadas no setor elétrico. Após a identificação das instituições que detinham em seus acervos patrimônio do setor elétrico, nove delas foram escolhidas para serem pesquisadas de forma mais aprofundada, a grande maioria no interior do estado e sendo cinco pertencentes à Rede Museu da Energia. A partir da metodologia elaborada, buscou-se analisar as exposições de longa duração e temporárias para compreender como ocorrem as ações de comunicação direcionadas a esse patrimônio do setor elétrico. Realizaram-se, também, entrevistas com funcionários dos museus para obter informações específicas sobre como ocorre o trabalho nessas instituições na atualidade e como as mentalidades desses profissionais refletiram na condução dos museus ao longo dos anos. Como resultado, resumidamente, observou-se que os museus identificados, excetuando os pertencentes à Rede Museu da Energia, são tradicionais e possuem problemáticas e lógicas discursivas que se voltam à história das cidades onde se situam. Sob diferentes contextos de implantação, esses museus detêm acervos compostos por objetos de naturezas diversas, além dos objetos eletrificados, como eletrodomésticos, e maquinários utilizados na produção de energia. 
Quadro 2. Museus existentes em municípios que sofreram emancipação. Fonte: Yagui, 2014.

\begin{tabular}{|c|c|c|c|c|c|}
\hline Usina & $\begin{array}{c}\text { Início } \\
\text { construção } \\
\text { (c)/ início } \\
\text { operação } \\
\text { (op) }\end{array}$ & $\begin{array}{l}\text { Proprietário } \\
\text { atual }\end{array}$ & Município & $\begin{array}{l}\text { Informações sobre } \\
\text { emancipação }\end{array}$ & $\begin{array}{l}\text { Museus nos } \\
\text { municípios que } \\
\text { sofreram } \\
\text { emancipação }\end{array}$ \\
\hline $\begin{array}{l}\text { PCH Gavião } \\
\text { Peixoto }\end{array}$ & Op. 1913 & CPFL & Gavião Peixoto & $\begin{array}{l}\text { Emancipou-se de } \\
\text { Araraquara em } \\
1995\end{array}$ & $\begin{array}{l}\text { Os museus de } \\
\text { Araraquara já } \\
\text { foram listados no } \\
\text { quadro } 1\end{array}$ \\
\hline PCH Lençóis & $\begin{array}{l}\text { C: } 1917(?) \\
\text { Op. } 1917\end{array}$ & CPFL & Macatuba & $\begin{array}{l}\text { Emancipou-se de } \\
\text { Lençóis Paulistas } \\
\text { em } 1924\end{array}$ & $\begin{array}{l}\text { Museu Alexandre } \\
\text { Chitto }\end{array}$ \\
\hline PCH Jaguari & $\begin{array}{l}\text { C: } 1917 \\
\text { Op. } 1919\end{array}$ & CPFL & Pedreira & $\begin{array}{l}\text { Emancipou-se de } \\
\text { Amparo em } 1896\end{array}$ & $\begin{array}{l}\text { Museu Histórico } \\
\text { Pedagógico } \\
\text { Bernardino de } \\
\text { Campos }\end{array}$ \\
\hline $\begin{array}{l}\text { PCH Boa } \\
\text { Vista }\end{array}$ & Op: 1913 & CPFL CLFSC & Sarutaía & $\begin{array}{l}\text { Emancipou-se de } \\
\text { Piraju em } 1959\end{array}$ & $\begin{array}{l}\text { Os museus de } \\
\text { Piraju já foram } \\
\text { listados no quadro } \\
1\end{array}$ \\
\hline & & & & Emancipou-se de & $\begin{array}{l}\text { Museu Histórico e } \\
\text { Pedagógico Casa de } \\
\text { Anhanguera }\end{array}$ \\
\hline PCH Rasgão & Op. 1925 & EMAE & Jesus & $\begin{array}{l}\text { Santana do } \\
\text { Parnaíba em } 1959\end{array}$ & $\begin{array}{l}\text { Museu Parnaibano } \\
\text { de Música } \\
\text { Benedicto Antonio } \\
\text { Pedroso }\end{array}$ \\
\hline \multirow{9}{*}{$\begin{array}{l}\text { UHE Henry } \\
\text { Borden }\end{array}$} & \multirow{9}{*}{ C: 1926} & \multirow{9}{*}{ EMAE } & \multirow{9}{*}{ Cubatão } & \multirow{9}{*}{$\begin{array}{l}\text { Emancipou-se de } \\
\text { Santos em } 1949\end{array}$} & Museu do Porto \\
\hline & & & & & $\begin{array}{l}\text { Centro de Memória } \\
\text { Esportiva Museu } \\
\text { Devaney }\end{array}$ \\
\hline & & & & & Museu do Surfe \\
\hline & & & & & $\begin{array}{l}\text { Memorial das } \\
\text { Conquistas }\end{array}$ \\
\hline & & & & & Museu Marítimo \\
\hline & & & & & $\begin{array}{l}\text { Museu da Imagem } \\
\text { e do Som de Santos }\end{array}$ \\
\hline & & & & & $\begin{array}{l}\text { Pinacoteca } \\
\text { Benedicto Calixto }\end{array}$ \\
\hline & & & & & $\begin{array}{l}\text { Museu de Arte } \\
\text { Sacra de Santos }\end{array}$ \\
\hline & & & & & Museu do Café \\
\hline
\end{tabular}




\begin{tabular}{|c|c|c|c|c|c|}
\hline & & & & & $\begin{array}{l}\text { Museu do Instituto } \\
\text { de Pesca }\end{array}$ \\
\hline & & & & & Museu do Mar \\
\hline $\begin{array}{l}\text { PCH } \\
\text { Votorantim }\end{array}$ & $\begin{array}{l}\text { C: } 1912(?) \\
\text { Op. } 1940\end{array}$ & \multirow{3}{*}{$\begin{array}{l}\text { Votorantim } \\
\text { Energia }\end{array}$} & \multirow{3}{*}{ Votorantim } & \multirow{3}{*}{$\begin{array}{l}\text { Emancipou-se de } \\
\text { Sorocaba no final } \\
\text { da década de } 1960\end{array}$} & $\begin{array}{l}\text { Casa de Aluísio de } \\
\text { Almeida }\end{array}$ \\
\hline \multirow{2}{*}{$\begin{array}{l}\text { UHE } \\
\text { Itupararanga }\end{array}$} & \multirow{2}{*}{$\begin{array}{l}\text { C: } 1911 \\
\text { Op. } 1914\end{array}$} & & & & $\begin{array}{l}\text { Casarão Brigadeiro } \\
\text { Tobias }\end{array}$ \\
\hline & & & & & $\begin{array}{l}\text { Museu da Estrada } \\
\text { de Ferro } \\
\text { Sorocabana }\end{array}$ \\
\hline $\begin{array}{l}\text { PCH } \\
\text { Quatiara }\end{array}$ & $\begin{array}{l}\text { C: } 1938 \\
\text { Op. } 1939\end{array}$ & $\begin{array}{l}\text { Votorantim } \\
\text { Energia }\end{array}$ & Rancharia & $\begin{array}{l}\text { Emancipou-se de } \\
\text { Paraguaçu } \\
\text { Paulista em } 1935\end{array}$ & $\begin{array}{l}\text { Museu e Arquivo } \\
\text { Histórico Jornalista } \\
\text { José Jorge Junior }\end{array}$ \\
\hline \multirow{3}{*}{$\begin{array}{l}\text { PCH Laranja } \\
\text { Doce }\end{array}$} & \multirow{3}{*}{$\begin{array}{l}\text { C: } 1928 \\
\text { Op. } 1929\end{array}$} & \multirow{3}{*}{$\begin{array}{l}\text { Votorantim } \\
\text { Energia }\end{array}$} & \multirow{3}{*}{ Martinópolis } & \multirow{3}{*}{$\begin{array}{l}\text { Emancipou-se de } \\
\text { Presidente } \\
\text { Prudente em } 1949\end{array}$} & $\begin{array}{l}\text { Centro de } \\
\text { Museologia, } \\
\text { Antropologia e } \\
\text { Arqueologia }\end{array}$ \\
\hline & & & & & $\begin{array}{l}\text { Museu de } \\
\text { Informática }\end{array}$ \\
\hline & & & & & $\begin{array}{l}\text { Museu Prefeito } \\
\text { Antônio Sandoval } \\
\text { Neto }\end{array}$ \\
\hline PCH Itatinga & $\begin{array}{l}\text { C: } 1906 \\
\text { Op. } 1910\end{array}$ & Outras & Bertioga & $\begin{array}{l}\text { Emancipou-se de } \\
\text { Santos em } 1991\end{array}$ & $\begin{array}{l}\text { Os museus de } \\
\text { Santos já foram } \\
\text { listados } \\
\text { anteriormente } \\
\text { nesse mesmo } \\
\text { quadro }\end{array}$ \\
\hline PCH Ester & $\begin{array}{l}\text { C: } 1930(?) \\
\text { Op. } 1930\end{array}$ & Outras & Cosmópolis & $\begin{array}{l}\text { Emancipou-se de } \\
\text { Campinas em } \\
1944\end{array}$ & $\begin{array}{l}\text { Os museus de } \\
\text { Campinas já foram } \\
\text { listados no quadro } \\
1\end{array}$ \\
\hline PCH Itaipava & Op. 1914 & Outras & $\begin{array}{l}\text { Santa Rosa do } \\
\text { Viterbo }\end{array}$ & $\begin{array}{l}\text { Emancipou-se de } \\
\text { São Simão em } \\
1910 \text { e só em } 1956 \\
\text { é instalada }\end{array}$ & $\begin{array}{l}\text { Museu Histórico } \\
\text { Simonense Alan da } \\
\text { Matta }\end{array}$ \\
\hline $\begin{array}{l}\text { PCH Santa } \\
\text { Fé }\end{array}$ & Op. 1929 & Outras & Nova Europa & $\begin{array}{l}\text { Emancipou-se de } \\
\text { Tabatinga em } \\
1953\end{array}$ & - \\
\hline
\end{tabular}

Fonte: Yagui, 2014.

A pesquisa realizada também indica que há influência das empresas do setor elétrico na musealização desse patrimônio por meio de doações e comodatos de objetos do setor elétrico a instituições museológicas e, até mesmo, por meio da implantação de museus pela própria companhia. 
O Museu do Porto de Santos, por exemplo, pertencente à Companhia Docas de Santos, apresenta em seu acervo uma coleção de objetos representativos da Pequena Central Hidrelétrica Itatinga, inaugurada em 1910 e gerida por esta companhia. Esse museu foi criado com o objetivo de apresentar a história do Porto e sua influência para o desenvolvimento da cidade onde se situa. A sala da exposição de longa duração do museu destinada à PCH Itatinga conta a história dessa hidrelétrica, a importância de sua construção e sua forma de funcionamento por meio de registros fotográficos, documentos e equipamentos, sendo grande parte dos objetos ferramentas representativas do trabalho realizado na usina e em suas dependências. Nota-se, portanto, que esse museu faz referência especialmente à questão da geração de energia.

Outro caso semelhante de museu que possui acervo composto por patrimônio do setor elétrico que remete à geração de energia é o Museu da Cidade de Salto Ettore Liberalesso implantado, na década de 1990, como ecomuseu na modalidade expográfica de museu-percurso (ROSSI; BARBUY, 1992). Além de sua sede, esse museu articula-se na cidade por meio de núcleos externos (Parque Rocha Moutonnée Parque das Lavras) e pontos de referência (Fábrica Brasital, Igreja Matriz, Praça XV de Novembro, Quintalões da Brasital, Escola Tancredo do Amaral, Antiga Estação Ferroviária, Monumento à Padroeira, Rio Jundiaí, Jardim Público e Concha Acústica, Cachoeira e Ponte Pênsil).

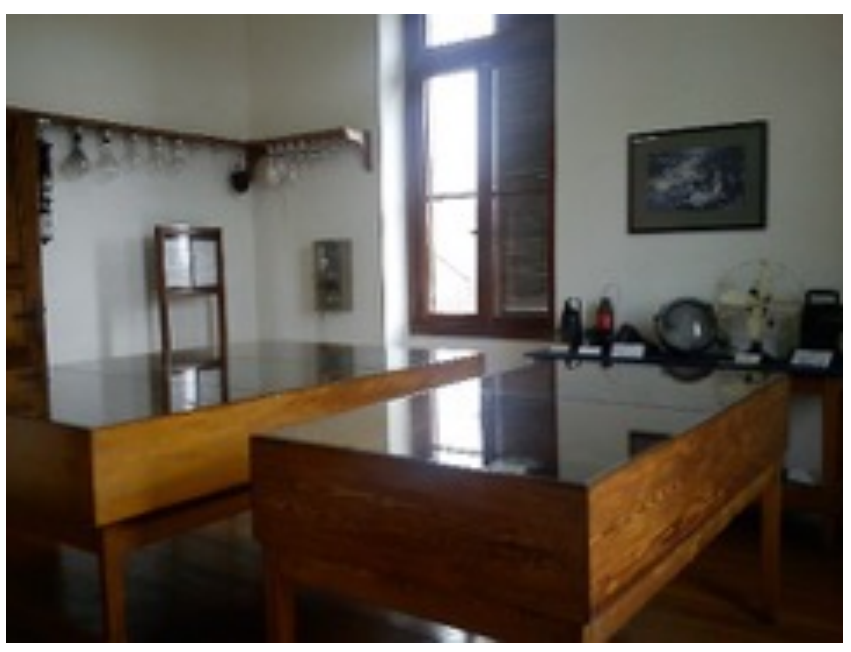

Figura 1. Museu do Porto de Santos, peças em exposição. 2013. Foto: Mirian Yagui.

O Parque das Lavras, núcleo externo do museu, abrange a área onde foi instalada a Pequena Central Hidrelétrica das Lavras, construída no rio Tietê em 1906. Além da exposição montada em um dos edifícios remanescentes da usina, composta basicamente por painéis que trazem referências históricas tanto da PCH das Lavras quanto da PCH Porto Góes, esta última ainda em funcionamento na atualidade, há também a casa de máquinas construída em granito rosa, onde é possível encontrar a turbina utilizada no período em que a PCH das Lavras ainda produzia energia.
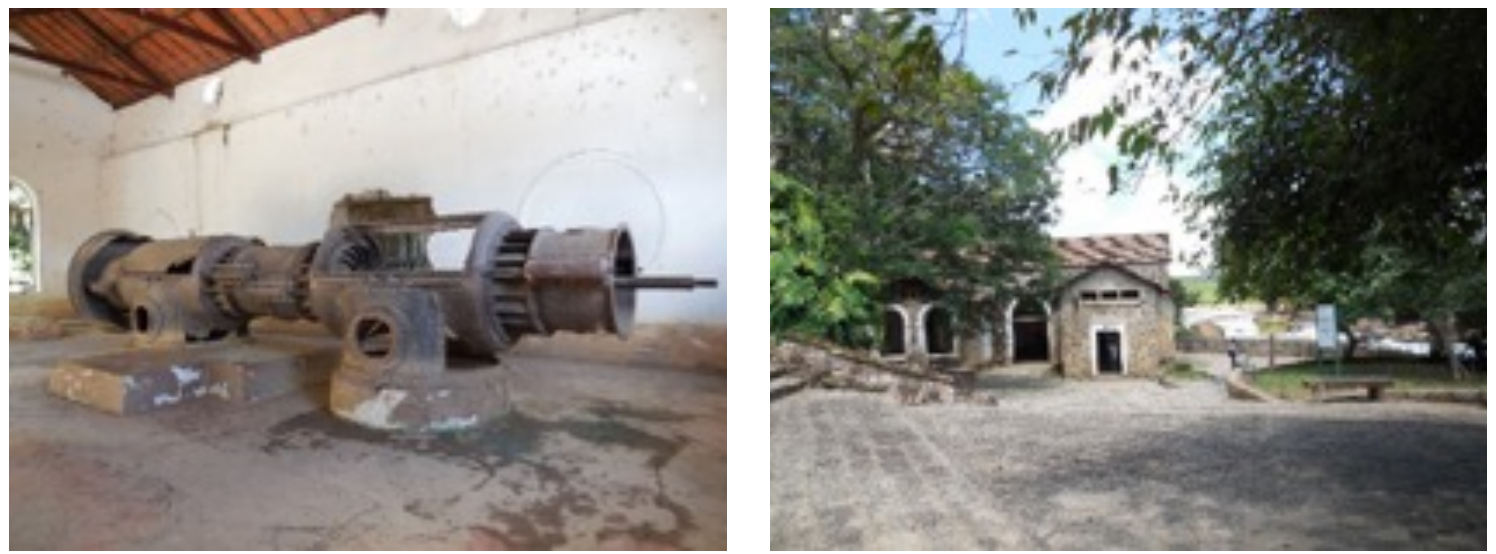

Figuras 2 e 3. Casa de máquinas e turbina da PCH das Lavras. 2014. Fotos: Mirian Yagui, 2014.

Em Piraju, cidade que possui ou está próxima de mais de cinco usinas hidrelétricas devido à presença do rio Paranapanema, foi criado o Museu Histórico Constantino Leman, que além de possuir acervo composto por objetos diversificados, em geral, de uso cotidiano em residências e no trabalho, apresenta também imagens e objetos utilizados na Hidrelétrica Jurumirim, bem como imagens da Pequena Central Hidrelétrica Paranapanema.

CURY, M.X.; YAGUI, M.M.P. A musealização do setor elétrico em São Paulo: construção de perspectivas para as 

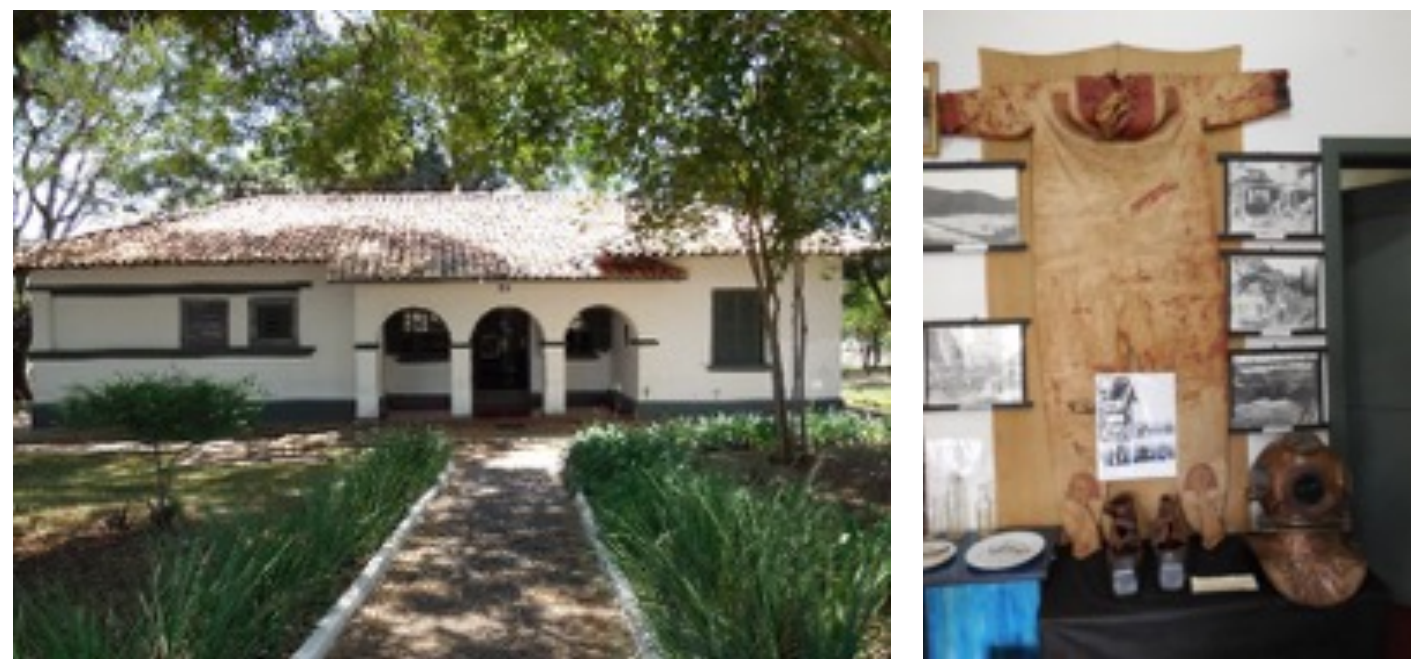

Figuras 4 e 5. Entrada do Museu Histórico Constantino Leman e peças do setor elétrico em exposição. Fotos: Mirian Yagui, 2014.

Mas a presença de usinas hidrelétricas nas cidades, não necessariamente condiciona a preservação de objetos que remetam apenas à geração de energia. Em Araraquara encontra-se o Museu Histórico e Pedagógico (MHP) Voluntários da Pátria, instituição que conta a história da cidade, por meio de objetos em grande parte doados por seus moradores que retratam a fauna, os minerais, bem como objetos indígenas e não indígenas de uso pessoal, compondo um acervo de aproximadamente 3000 itens de diversas categorias. Em 1996, a Companhia de Força e Luz (CPFL) cedeu em comodato uma coleção de objetos do setor elétrico ao MHP Voluntários da Pátria, caracterizado por representar o trabalho no setor elétrico, a presença de eletricidade no cotidiano doméstico e a iluminação pública.
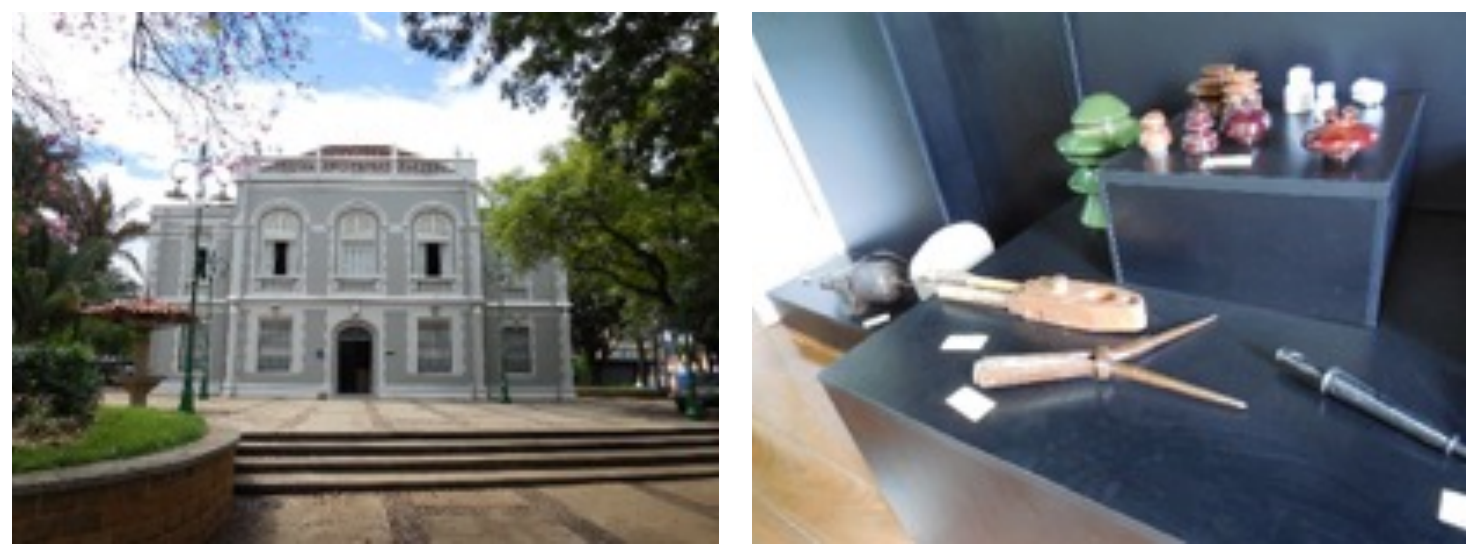

Figuras 6 e 7. Fachada do MHP Voluntários da Pátria e peças do setor elétrico em exposição.

Fotos: Mirian Yagui, 2014.

Talvez sejam mais evidentes as motivações para a musealização do patrimônio do setor elétrico voltado à geração de energia, já que as usinas hidrelétricas conseguem resistir ao tempo, diferentemente das estruturas que compõem a transmissão de energia, por exemplo. Além disso, os edifícios da usina e os maquinários em si constituem o acervo e já estão expostos dentro do seu contexto de uso, podendo, também, compor um museu de território devido às questões paisagísticas e ambientais intrínsecas.

A identificação de que ocorre a musealização do patrimônio do setor elétrico no estado é tão importante quanto à reflexão sobre a ausência do patrimônio do setor elétrico nos acervos de grande parte dos museus estudados, pois nos aproxima da compreensão de como os sujeitos envolvidos no processo de musealização veem o patrimônio, quais as motivações que os levam a musealizar determinados objetos e qual a concepção de patrimônio que os museus existentes nas proximidades das PCH possuem. 


\subsection{A rede de Museus da Energia: um modelo em discussão}

Há reconhecidamente, desde a década de 1980, iniciativas de institucionalização de coleções que resultaram na criação dos primeiros museus do setor elétrico por empresas paulistas como a Eletropaulo, a CESP e a CPFL (BLOISE, 2000).

Tais iniciativas empreendidas direta e indiretamente pelas empresas são reflexo das mudanças ocorridas em sua forma de gestão e reflexão sobre as responsabilidades que elas deveriam ter como membros da sociedade, voltadas aos aspectos econômico, social, ambiental, cultural e legal. Com isso, passaram a assumir responsabilidades nesse sentido e atuar com a memória institucional, que na atualidade se define como a [...]

\section{[...] (re) construção de fatos e acontecimentos significativos da trajetória e das experiências da organização, selecionados e (re) organizados com o objetivo de estimular o processo de (re) construção de uma identidade comum entre esta $e$ seus públicos de interesse" (BARBOSA, 2012, p. 04).}

Na verdade, não podemos definir tais iniciativas como museus, por não abrangerem o conjunto de ações inerentes a uma instituição museológica: a curadoria. Eram sim exposições com a função de apresentar o acervo preservado, produzidas muitas vezes em datas festivas da empresa, abordando temas técnicos voltados aos funcionários da empresa, aposentados, especialistas, estudantes e parceiros comerciais. Em geral apresentavam objetos utilizados nos escritórios das empresas, tais como relógios, mesas, máquinas registradoras, placas comemorativas, e poucos eram os documentos que retratavam a memória do trabalho e o cotidiano das empresas.

Em 1986, a Companhia Paulista de Força e Luz implantou o Museu Histórico da CPFL, localizado na Subestação Campinas-Centro. Já no ano de 1987, exposições como a Energia, patrocinada pela CESP e a Tecnologia do Álcool, foram promovidas pela Fundação Museu da Tecnologia de São Paulo, com apoio financeiro da Secretaria de Ciência, Tecnologia e Desenvolvimento Econômico. Um ano mais tarde, em 1988, a Eletropaulo criou o primeiro Museu da Eletricidade, localizado na agência da Eletropaulo em Jundiaí.

A década de 1990 foi bastante profícua nesse sentido, sendo primeiramente criado pela Cesp o Museu da Energia na Usina do Corumbataí, em Rio Claro. Nesse mesmo período, a Eletropaulo, por meio de seu Departamento de Patrimônio Histórico, idealizou um projeto museológico que por ser [...]

\section{[...] de caráter moderno e abrangente, ele combina a noção de centralidade da orientação técnica do museu, com a concepção de vanguarda dos "núcleos museológicos" descentralizados; nestes, a cultura material da empresa é apresentada nos próprios locais em que foi produzida, contextualizando a história das relações do homem com a máquina e com o seu espaço físico (DINIZ TRÓIA;FERREIRA,1990, p. 51).}

Tinha como proposta a criação de um museu descentralizado, devido à dispersão territorial do acervo da empresa, que seria formado por núcleos museológicos e um núcleo central, responsável pela convergência de toda a rede. A ideia de núcleos museológicos visava à musealização de locais que ainda estavam em operação, o que permitiria trabalhar o patrimônio de forma ampla. 0 projeto levava em consideração as inúmeras iniciativas de institucionalização de acervos e programas de visitas já realizadas por funcionários e setores da Eletropaulo.

Com isso pensou-se, inicialmente, na musealização da Usina Elevatória Edgard de Souza e da Usina de Rasgão por seu significado cultural ultrapassar o âmbito da Eletropaulo, mas mesmo o projeto não sendo efetivamente aplicado, tornou-se uma referência para a implantação da Rede Museu da Energia alguns anos mais tarde.

Outra ação da Eletropaulo, em 1994, foi a criação de mais um Museu da Eletricidade, localizado na agência da Eletropaulo em Itu, à semelhança do Museu da Eletricidade criado em Jundiaí no ano de 1988. 
Com a criação da Fundação Patrimônio Histórico da Energia de São Paulo, em 1998, instituição privada com o objetivo de preservar o acervo de grandes empresas do setor energético do Estado de São Paulo que estavam em processo de privatização, houve uma reflexão mais aprofundada sobre a musealização desse patrimônio e a importância de sua preservação, pesquisa e comunicação. Essas ações foram viabilizadas a partir da implantação do Núcleo de Documentação e Pesquisa e da Rede Museu da Energia.

Em 2004, essa Fundação incorporou à sua missão a questão do saneamento, alterando sua denominação para Fundação Patrimônio Histórico da Energia e Saneamento ou, de forma sintetizada, Fundação Energia e Saneamento.

A Rede Museu da Energia é formada por sete unidades: três imóveis urbanos (Itu, Jundiaí e São Paulo) e quatro pequenas centrais hidrelétricas (Salesópolis, São Valentim, Jacaré e Corumbataí), sendo esta última a única usina hidrelétrica tombada pelo Conselho de Defesa do Patrimônio Histórico, Arqueológico, Artístico e Turístico do Estado (Condephaat). As Centrais Hidrelétricas São Valentim e Jacaré não foram efetivamente musealizadas, entendendo-se com isso que não fazem parte da comunicação na estrutura museal.

No caso das PCH pertencentes à Fundação, planejou-se a musealização considerando não apenas seu valor histórico e arquitetônico, mas também a sua função inicial: geração de energia. Com isso, atrelando sua origem à nova função, obtêm recursos financeiros e possibilitam a imersão dos visitantes dos museus no processo de geração de energia.

Os Museus da Energia de Salesópolis e Rio Claro, implantados nas pequenas centrais hidrelétricas, possuem maior facilidade na comunicação de seu acervo, pois pelo fato de se constituírem como museus de território por abrangerem edifícios, maquinários, represa e todo o ambiente em seu entorno, sua visitação permite vivenciar o processo de geração de energia como um todo, inclusive possibilitando compreender como o meio ambiente influi nesse processo.

No caso dos imóveis urbanos, as exposições foram planejadas abordando temas diferentes, mas que se complementam. O Museu da Energia de Itu, situado em sobrado que foi agência de atendimento ao público de companhias do setor elétrico como a Ituana, a Eletropaulo e a Bandeirante Energia S.A., trata o uso doméstico da energia durante os séculos XIX e XX por meio de objetos e equipamentos a gás e elétricos como lâmpadas, lamparinas, medidores de consumo de energia, aquecedores de água, vitrolas, rádios, fogões, geladeira, chuveiro, batedeiras, ventiladores dentre outros. Já o Museu da Energia de Jundiaí, situado na antiga subestação de Jundiaí, construída pela Companhia Light, tem o intuito de apresentar questões sobre a geração, transmissão e distribuição de energia. No caso do Museu da Energia de São Paulo busca-se abordar a história da energia no estado, o processo de modernização e industrialização, bem como as transformações que a energia elétrica incutiu no cotidiano da sociedade.
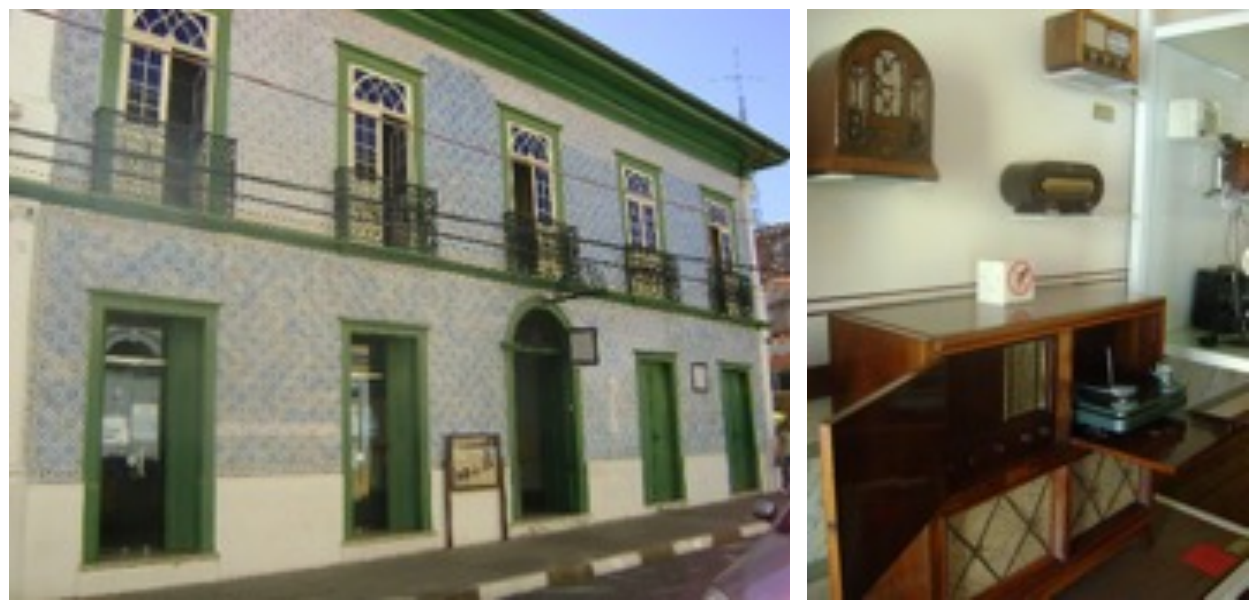

Figuras 8 e 9. Fachada do Museu da Energia de Itu e objetos em exposição. Fotos: Mirian Yagui, 2013.

CURY, M.X.; YAGUI, M.M.P. A musealização do setor elétrico em São Paulo: construção de perspectivas para as usinas hidrelétricas. Labor \& Engenho, Campinas [SP] Brasil, v.9, n.1, p.104-134, jan./mar. 2015.

Disponível em: www.conpadre.org 

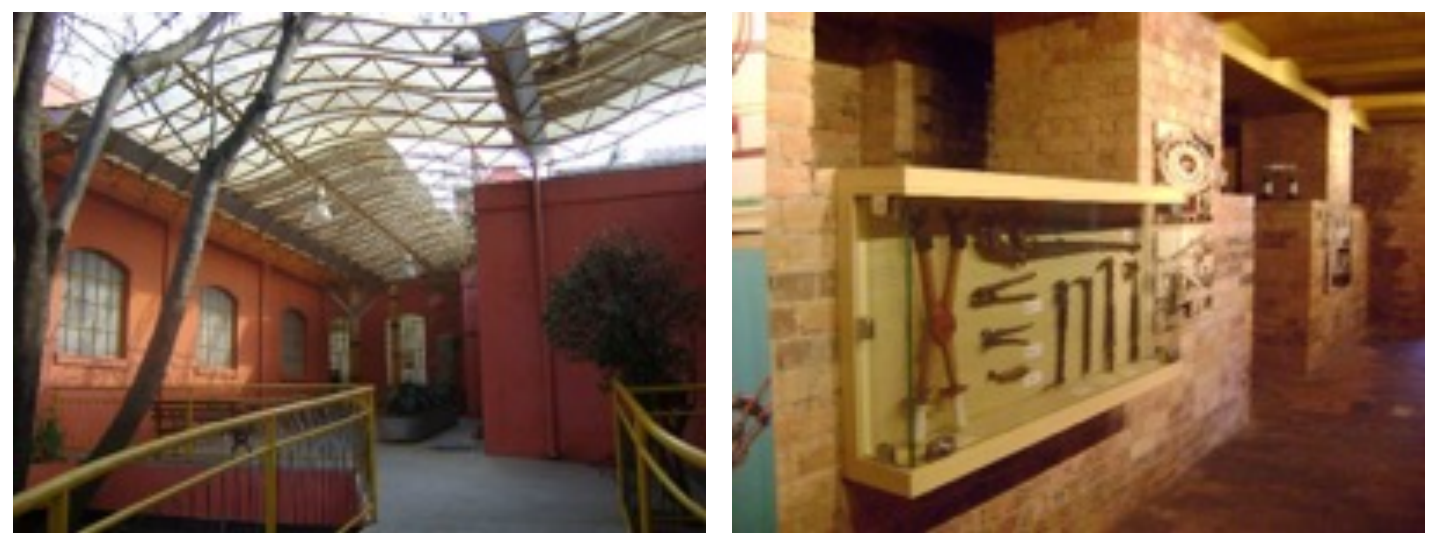

Figuras 10 e 11. Interior do Museu da Energia de Jundiaí e objetos em exposição. Fotos: Mirian Yagui, 2013.

Todas as unidades da Rede Museu da Energia realizam ações educativas de forma bastante dinâmica, utilizando-se de salas criadas em todas as unidades para este fim, pensando nas vivências e trocas entre o espaço museológico e os visitantes. Em geral, abordam questões como as diferentes formas de geração de energia, sua transmissão e distribuição, bem como os impactos gerados ao meio ambiente e os aspectos históricos, patrimoniais e sociais.

No que diz respeito aos objetos musealizados, de modo geral, os maquinários são encontrados apenas nas usinas hidrelétricas, enquanto que nos museus urbanos constam ferramentas e instrumentos de trabalho em geral, lâmpadas e outros objetos eletrificados como eletrodomésticos, imagens e, em alguns casos, documentos.

Quadro 3. Síntese da proposta da Rede Museu da Energia. Organizado por Yagui.

\begin{tabular}{|l|l|l}
\hline Unidade da Rede Museu da Energia & Imóvel/PCH & Enfoque temático \\
\hline Museu da Energia de São Paulo & Casarão & $\begin{array}{l}\text { História da energia no estado de São Paulo e o } \\
\text { processo de modernização e industrialização }\end{array}$ \\
\hline Museu da Energia de Jundiaí & Subestação & $\begin{array}{l}\text { Geração, transmissão e distribuição de energia } \\
\text { elétrica }\end{array}$ \\
\hline Museu da Energia de Itu & Casarão & A energia no cotidiano e seu uso doméstico \\
\hline Museu da Energia de Salesópolis & PCH Salesópolis & Usina-Parque (usina hidrelétrica musealizada) \\
\hline Museu da Energia de Rio Claro (PCH) & PCH Corumbataí & Usina-Parque (usina hidrelétrica musealizada)
\end{tabular}

A gestão desse patrimônio é complexa, por se tratar de objetos com diferentes tipologias, contemplando edifícios, maquinários dentre outros elementos, o que demanda equipe ampla, além de verba para mantenimento e realização das ações de curadoria. Essas e outras questões influenciaram o fechamento do Museu da Energia de Jundiaí no ano de 2014 e a abertura apenas para visitas agendadas, sem acompanhamento de educador, no Museu da Energia de Rio Claro.

A rede Museus da Energia é um modelo representativo de musealização do patrimônio do setor elétrico e a reflexão sobre a forma como se deu sua implantação e como ao longo dos anos tem realizado suas ações de preservação, pesquisa e comunicação, é primordial para vislumbrarmos outras possibilidades de musealização desse patrimônio. Por tal motivo, com base na experiência de implantação e de atuação da Rede Museu da Energia, é possível até mesmo considerarmos o surgimento de uma nova forma de classificação museal, o museu da energia, que de acordo com a composição de sua coleção, define-se como [...]

[...] instituição museológica com acervo que traz referências da geração, transmissão e distribuição de energia produzida por meio de diferentes fontes, na qual a pesquisa, 
preservação e comunicação deve considerar toda a amplitude desse patrimônio, ou seja, compreendê-lo como importante vetor para o desenvolvimento técnico-científico e como processo histórico e social, considerando as transformações que incutiu na sociedade e, especialmente, em seu cotidiano (YAGUI, 2014, p. 152).

No entanto, mesmo vislumbrando a possibilidade do surgimento de uma nova classificação museal, não devemos esquecer que a questão energética permeia instituições museológicas que possuem outras classificações por deterem coleções com problemáticas diversas, como museus históricos, museus de cidade e museus de ciência. Mas destacamos com ênfase a questão da classificação, para reafirmar a complexidade do patrimônio do setor elétrico.

\section{Reflexões para a musealização: as perspectivas das usinas de São Paulo}

Associada ao termo musealização, musealidade é um valor atribuído a algo devido a seu potencial de musealização.

Ao nos referirmos à musealização do setor elétrico no estado de São Paulo, cercando as PCH e algumas UHE criadas entre 1890 e 1960, não estamos com isso afirmando o que estamos fazendo projetando um museu que compreende um complexo hidrelétrico -, mas destacando que há uma musealidade inerente às usinas; é a possibilidade de musealização que queremos discutir de fato e que se torna relevante para o estado da "arte" da preservação do setor elétrico.

Para o exercício que se apresenta, foram realizadas visitas a muitas das usinas criadas no período, para uma compreensão, mesmo que ampla, da musealidade do setor. A partir da observação das PCH e UHE se buscou "projetar" o potencial de musealização e, com isso, em grande medida, foi necessária uma percepção do lugar e de como ele poderia ser um museu, muitas das vezes em concomitância ao funcionamento da PCH ou UHE, ou seja, estar em funcionamento não seria um impeditivo para ser museu, ao contrário, agregaria valor a ele. A projeção sempre levou em conta também que esse museu hipotético operaria a partir da curadoria, para não se tornar um espaço de e/ou com exposição. Dessa forma, as premissas colocadas para o museu que se busca são:

a) uma especialização institucional para o patrimônio que pode ocorrer em muitos espaços e de muitas formas,

b) a institucionalização vê a separação de áreas públicas, técnicas e restritas,

c) uma gestão que se orienta por um Plano Museológico,

d) a organização de programas de atuação, e

e) a estruturação da comunicação para distintos setores sociais.

Ao buscar na bibliografia internacional situações em que sítios industriais e/ou usinas hidrelétricas foram preservados, encontramos diversas qualificações: reconversão, reutilização, revitalização, regeneração, refuncionalização, todas formas de valorização do patrimônio industrial por um uso específico. É justamente o reuso que nos interessa, na complexa destinação do patrimônio a uma função diferente da original, mesmo que a usina esteja ainda em atividade. Dessa forma, discutimos como ir além da restauração e da conservação, embora estas sejam essenciais, para se chegar a uma utilização pública. Para tanto, os museus vêm demonstrando ser uma estratégia viável e singular, pois a sua natureza institucional aproxima, pelas ações de curadoria, o patrimônio da sociedade, além de cumprir suas funções básicas de pesquisa e educação.

Antes, no entanto, de chegarmos na atualidade com tantas expectativas e algumas perspectivas, há de se considerar que no Brasil, embora tenham ocorrido pontualmente algumas reflexões e propostas de ação voltadas ao patrimônio industrial, o país ainda não tem presença substancial no processo de preservação e valorização desse patrimônio.

Na década de 1980, por exemplo, Waldisa Russio Guarnieri, em sua tese de doutorado, apresentou uma proposta de implantação de um museu de indústria no estado de São Paulo. 0 intuito era constituir um museu que atuasse com a ação industrial sob a perspectiva de um processo social, 
buscando referências não apenas do passado, mas também a preservação do presente. Para a autora,

\begin{abstract}
um museu industrial não é apenas um museu de máquinas: é um museu de máquinas feitas pelo Homem. Um museu industrial não é apenas um museu de produtos: é um museu de bens produzidos pelo Homem e para consumo do Homem. Um museu industrial não é apenas a epopeia das chaminés: é o mundo subterrâneo das casas de máquinas, é o registro dos movimentos sociais e das lutas de empresários que souberam pensar em seu país... É um museu dinâmico pelas próprias tensões sociais que registra. (GUARNIERI, 1980, p. 12).
\end{abstract}

A proposta visava à implantação da sede do museu no município de São Paulo, mas que atuaria em diálogo com museus de indústria implementados em todo o estado, articulando esse patrimônio em âmbito intermunicipal. No entanto, tal modelo nunca foi implementado.

No contexto internacional, por sua vez, há um setor que se mobiliza há muito. Temos notícias de iniciativas "que remontam ao século XVIII com a criação, em 1794, do Conservatoire National des Artes et Métiers, mais tarde transformado em Musée des Arts et Metiers de Paris (MATOS; SAMPAIO, 2014, p. 96), outras do século XIX que se deram na esteira das Exposições Universais ou paralelamente motivadas também por elas, resultando em uma quantidade e variedade bastante grande de museus comercial, científico e/ou tecnológico, de técnica, engenharia, industrial -, em diversos países, muitos entre 1880 e a década de 1930 em países como Bélgica, Portugal, Alemanha, Suíça, Japão, Estados Unidos. Nessa trajetória é que na década de 1980 ganham força os processos de musealização de sítios industriais, agora com as contribuições da nova museologia (MATOS; SAMPAIO, 2014, p. 96-9), tendo como um dos expoentes o Ironbridge Gorge Museum Trust na Inglaterra, representante de um campo que consolidava a arqueologia e o patrimônio industrial, museu fortemente influenciado pelo modelo "museu a céu aberto".

As usinas hidrelétricas que ora analisamos em vistas à musealidade, não estão abandonadas, são propriedades de organizações, como a Fundação Energia e Saneamento, ou, na grande maioria, de empresas após a privatização no fim dos anos de 1990. Sendo assim, a musealização que ora se vislumbra refere-se ao setor industrial, mas também empresarial, visto que não podemos separar uma perspectiva da outra. Diga-se, essa visão não é recente, pois outrora, então empresas estatais, CPFL, Cesp e Eletropaulo, criaram seus museus, mesmo que embrionariamente, para preservação de suas memórias. Então, passamos a uma análise parcial e transversamente, pois considera-se do conjunto visitado algumas selecionadas para os exemplos dados.

\title{
3.1. A musealização das usinas hidrelétricas: um exercício
}

Das expedições em realização pelo projeto Eletromemória, o que compreendeu 40 usinas de um total de cerca de 60, foi possível observar as pequenas centrais hidrelétricas e destacar algumas delas para discussão: PCH Porto Góes (1928) e UHE das Lavras (ambas no município de Salto), UHE Fojo (de 1930, Campos do Jordão), PCH Gavião Peixoto (1913, Gavião Peixoto), PCH Isabel (1915, Pindamonhangaba e Campos do Jordão), UHE Henry Borden (1924-6, Cubatão), PCH Itatinga (1906-10, Bertioga), PCH Monjolinho (1893, São Carlos), Usina Elevatória da Traição (1940, em São Paulo).

O município de Salto, onde se encontra a Pequena Central Hidrelétrica Porto Góes e a Usina das Lavras, constitui-se numa Estância Turística com atrativos naturais e culturais. Parte desses atrativos compõe o Museu da Cidade de Salto Ettore Liberalesso, um museu de percurso constituído por pontos de referência e núcleos.

A ideia inicial do Museu da Cidade de Salto, implantado em 1990, foi articular o território da cidade por [...]

[...] uma Sede, no edifício da antiga Sociedade Italiana, dois núcleos externos (o Parque Usina das lavras e o Parque Rocha Moutonnée) e dez Pontos de Referências, tais como a

CURY, M.X.; YAGUI, M.M.P. A musealização do setor elétrico em São Paulo: construção de perspectivas para as 
fábrica de tecidos Brasital, uma das primeiras instaladas em salto, o Quintalão de uma Vila Operária ou a própria cachoeira (ROSSI; BARBUY, 1992, p. 58).

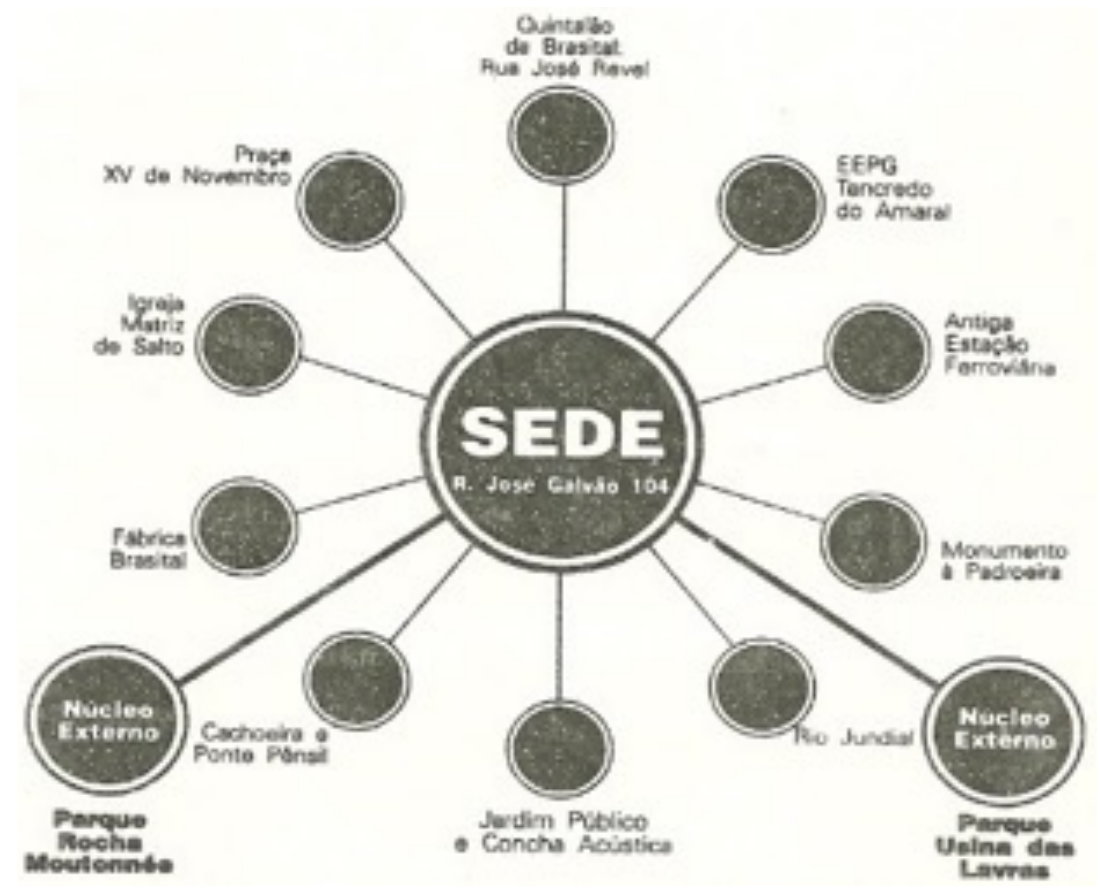

Figura 12. Estrutura patrimonial do Museu de Salto. Fonte: Rossi; Barbuy, p. 59, 1992.

No entanto, após anos de sua implantação, essa articulação não ocorre efetivamente pelos responsáveis pela sua gestão. Nesse caso específico, na atualidade, acreditamos ser necessária a avaliação e a requalificação do Museu da Cidade de Salto, buscando retomar o sentido de museu de cidade que, muito além da guarda de acervos, deve realizar a leitura e problematização desse território no qual está inserido e sobre o qual atua e se relaciona. Essa requalificação abrangeria a inclusão da UHE Porto Góes como um de seus pontos de referência, articulando a usina com o território, e considerando:

- a sua história, intrínseca à industrialização da cidade, constituindo-se, também, num remanescente da arquitetura industrial na região;

- as atividades tradicionalmente exercidas dentro de sua estrutura, como o seu funcionamento e produção de energia elétrica; e

- a relação da usina com o meio ambiente, abordando questões sobre o rio, os impactos causados pela usina, a poluição, bem como a problemática referente à produção e uso adequado da energia elétrica.

Nesse sentido, exposições itinerantes que abordem tais aspectos poderiam ser apresentadas não apenas na usina Porto Góes, mas num percurso pela cidade, permanecendo nos pontos de referência e núcleos externos do Museu da Cidade de Salto.

O diálogo entre as usinas Porto Góes e das Lavras, por meio de ações educativas, por exemplo, deve ser constante, aproveitando o potencial de inter-relações existentes entre ambas, tanto historicamente no que diz respeito à sua fundação, quanto na atualidade, os diferentes rumos traçados por esses patrimônios industriais. Para que isso ocorra, entretanto, será necessário o diálogo e o mútuo interesse da EMAE, proprietária da PCH Porto Góes, e a Prefeitura de Salto, responsável pela UHE das Lavras. Havendo a interligação, ações como um circuito de visitação, exposições integradas em ambas as usinas, também são possibilidades que permitirão confrontar duas realidades voltadas ao patrimônio do setor elétrico situadas nesse território, bastante distintas. 
No que tange à Usina do Fojo (1930) situa-se em cidade turística com muitos atrativos naturais e culturais. A cidade abriga o renomado Festival de Inverno de Campos do Jordão. Dentre as instituições museológicas temos: Museu Felícia Leirner (Secretaria de Estado da Cultura de São Paulo), o Palácio Boa Vista (Acervo Artístico Cultural dos Palácios do Governo do Estado de São Paulo), a Casa da Xilogravura (USP) e o Museu da História, Imagem e Som. No que se refere à conservação ambiental, Campos do Jordão detém o Parque Estadual de Campos do Jordão - o Horto Florestal - e o Parque Estadual Mananciais Campos do Jordão (Governo do Estado de São Paulo), além de outras reservas municipais, estaduais e federais.

O potencial de musealização da Usina do Fojo reside, primeiramente, na sua história e na sua relação com a cidade. Por exemplo, temas da eletrificação e da ferrovia não constam de nenhum espaço museológico local. Outro aspecto relevante refere-se ao Parque Estadual do Fojo, que abrange as instalações da antiga Usina e a Reservatório de Água da Sabesp e áreas de lazer. Nesse conjunto há um uso anterior do espaço: a colônia de férias dos antigos funcionários da Cesp. Outro aspecto da musealização compreende o complexo hídrico da Serra da Mantiqueira com seus rios, riachos e nascentes. Nesse sentido, há que se considerar também Santo Antônio do Pinhal e São Bento do Sapucaí.

Para a Usina do Fojo vemos o potencial histórico e hídrico como temas a serem explorados pela musealização. Para tanto, a usina poderia ser um sítio histórico e local central com exposições que explorassem o registro fotográfico e outros documentos e aparatos de demonstração (a exemplo dos centros de ciência). A partir desse núcleo se incorporam à ideia de musealização as bacias dos rios Sapucaí-Guaçu e Sapucaí-Mirim e seus cursos d’água, para associar um museu de ciência e tecnologia a um museu de território que tivesse como problemática a cidade, a energia elétrica, o uso da água, a coleção hídrica e o meio ambiente. As antigas instalações da colônia de férias da Cesp devem, nesse sentido, ser aproveitadas para recepção e ações de educação, assim como para dar conforto e/ou instalação a grupos de estudantes que desejarem realizar estudo de meio nesse contexto.

A PCH Gavião Peixoto (1913, Gavião Peixoto) tem suas particularidades quanto ao potencial de musealização. Além de toda a musealidade - conjunto arquitetônico com a casa de máquinas e vila operária, histórico, paisagístico, maquinaria etc., essa usina teve seu equipamento trocado, visando a uma modernização. Esse maquinário foi, então, separado, preservado e exposto em estrutura coberta. Foi substituído, mas manteve-se no lugar com seu grande porte e elegância apresentado para contemplação. Outro aspecto a destacar, considerando um potencial de musealização, é a circulação. Primeiro, o acesso à PCH é simples, apesar do trecho de estrada de terra. Na usina, por outro lado, a circulação para pessoas com dificuldades de locomoção (pela idade ou outra dificuldade) é possível, é o suficientemente plano para isso, desde que havendo algumas adequações. Alguns dos diversos elementos integrantes do todo estão "próximos": as casas da vila operária, o maquinário antigo exposto, a paisagem, o campo de futebol. 0 paisagismo bem cuidado é outro fator que deixa o lugar muito agradável e propício a algumas horas de lazer cultural. A sinalização própria da usina, para a segurança de quem transita nela, é educativa também, nos faz pensar sobre o espaço e sobre as normas de cada lugar. As antigas residências dos funcionários poderiam ser restauradas e mantidas como "objetos" do museu, mas também como lugar de conforto e encontro, exposição, seções de vídeo, atividades etc.

A PCH Isabel (1915, Pindamonhangaba) tem suas particularidades: acesso por dois municípios, Pindamonhangaba e Campos do Jordão. Trata-se de usina em grande extensão territorial. Pelo acesso de Pindamonhangaba encontramos a Vila operária, a casa de máquinas, vista ascendente da tubulação, paisagismo cuidado e mata circundante. A circulação é possível com certa facilidade, mediante adequações, mas não há dificuldades com grandes elevações, a via de acesso a muitos dos elementos patrimoniais se dá por rua asfaltada com leve inclinação. 0 patrimônio que se encontra nessa área é singular, a paisagem diversificada e densa. Quanto ao acesso por Campos do Jordão, a situação é outra, existe grande potencial de musealização, mas a musealidade diversifica, entendendo que temos dois espaços de visitação, que podem ou não serem visitados sequencialmente e num mesmo dia. Mas, por Campos do Jordão, a parte alta da usina, há uma longa caminhada, alguns trechos com subidas íngremes por escadas, até se chegar ao ponto que avistamos a casa de máquinas a centenas de metros abaixo. Uma bela paisagem ao redor e ao longo 
do olhar, um bom exemplo de mata preservada. Dessa forma, vimos a PCH Isabel como lugar especial para se tratar as questões ambientais, históricas e territoriais (se enxerga o território desde acima), envolvendo o visitante na observação e na circulação em meio a um lugar aparentemente distante do meio urbano, mas tão próximo dele.

A UHE Henry Borden (1924-6, Cubatão) e a PCH Itatinga (1906-10, Bertioga) estão no litoral do estado de São Paulo. Ambas são privilegiadas museologicamente falando. A usina Henry Borden tem dois acessos, como a PCH Isabel. Um deles se dá pela Serra do Mar, na divisa entre Cubatão e São Bernardo do Campo. Nesse lugar há a barragem, construções históricas, maquinário, um casarão imponente e relativamente bem conservado, por enquanto, uma paisagem que rodeia a usina com mata atlântica. Do topo da usina, circulando com carro, sai um trólei, com a identificação "Polo Ecoturístico Caminhos do Mar", sinal de uso público recente, embora desativado momentaneamente. Pelo trólei é possível descer até a parte de baixo da UHE, ou por carro pela estrada até cidade de Cubatão. Abaixo, há um pátio industrial e uma vila residencial ativa, com moradores, comércio e infraestrutura em geral, como o bairro que é. Ou seja, os profissionais que trabalham na usina vivem aí com suas famílias, o que eles têm a dizer sobre o trabalho, a sociabilidade e a cultura desse lugar? No pátio da usina, na área interna da usina, há diversas construções (o escritório administrativo e diversas oficinas de trabalho, elétrica, carpintaria, mecânica, encanadores), paisagismo e a paisagem serra acima, a cidade de Cubatão do lado de fora. Em uma placa há um mapa esquematizado com a demarcação de toda área de baixo da usina e a preocupação de discriminar as espécies da flora presentes no paisagismo dos jardins, 68 espécies com nome popular, nome científico e origem. Tanto no escritório administrativo quanto na casa de máquinas há peças de maquinaria em desuso, fotografias históricas, grandes desenhos feitos a mão, telefones, ventiladores, mobiliário do escritório - todos com a preocupação de expor, algumas peças com etiquetas de identificação - e documentação arquivística. Na área externa há a usina subterrânea: entra-se nela. Há fotos da construção da usina subterrânea (1954 a 1962) expostas em uma parede, com preocupação expográfica: composição de todos os elementos, título, tamanho de reprodução, alinhamento entre elas, etiqueta informativa e livro de registro de visitação. Em suma, a UHE Henry Borden tem uma vocação museológica, o que é facilmente perceptível devido à ação dos agentes que explicitaram essa vocação: os funcionários. Então, se hipoteticamente todas as usinais são musealizáveis, algumas delas tem vocação especial. Mas, em qualquer que seja o processo, o envolvimento dos funcionários, na ativa ou já aposentados, faz parte desse processo.

A PCH Itatinga (1906-10, Bertioga), por sua vez, inspira museu, por várias razões. A casa de máquinas, o maquinário, a barragem, a vila de residências de operários com escola, igreja e outros serviços etc. Mas, o ponto central é outro, mais abrangente. 0 primeiro acesso à PCH é por uma balsa e depois por um bonde. Antes da travessia avista-se um mangue e, ao longe, a Serra do Mar. 0 bonde nos leva até a vila operária e demais núcleos, todos próximos, e a partir daí o percurso é a pé. A casa de máquinas (com seu piso hidráulico, azulejos e outros elementos arquitetônicos, painéis de ferramentas J. M. Voith e outros itens) e a maquinaria (com vista geral desde o mezanino superior) são históricas, apesar das modernizações, e está junto a oficinas (de usinagem) e outras construções antigas. 0 acesso ao alto se dá por trólei, a subida permite uma visão singular da baixada santista, além da mata atlântica pela qual atravessamos. Ao alto, depois de uma caminhada, chega-se à barragem. A Vila operária é singular, composta por diversas residências, pequenos conjuntos geminados pintados de amarelo ocre, a antiga escola EPFF de Itatinga, a Capela Nossa Senhora da Conceição (inaugurada em 1942) com arquitetura ricamente ornada com azulejos e vitrais. Uma das casas usadas atualmente para recepção de visitantes mantém algum mobiliário antigo. A parte de baixo da usina permite uma boa locomoção, lembrando que há a balsa e o bonde, pois não apresenta declive acentuado. 0 acesso à parte superior, por sua vez, exige o trólei e, após este, uma caminhada de alguns quilômetros, poucos, mas dificultados por ser mais uma trilha facilitada, para que se chegue à barragem. É o conjunto descrito que nos dá inspiração para que a PCH seja vista na sua musealidade.

A PCH Monjolinho, São Carlos, é a usina mais antiga de São Paulo, 1893. Há na usina uma musealidade, certamente, pela historicidade, e conjunto de maquinário, o edificado, hídrico e paisagístico, somado ao fato de estar dentro da cidade de São Carlos, pois a cidade cresceu ao seu 
redor. A casa de máquinas está lá, com o equipamento, as tubulações, a arquitetura, a natureza, a sujeira, a poluição, a avenida e seus carros passando sem perceber a PCH.

O interessante da problemática da musealização da PCH Monjolinho é que, teoricamente, ela já está musealizada, pois a operadora criou em 2002, ano de seus 90 anos, o Museu da Energia da Usina de Monjolinho ou Museu da Energia da CPFL. De fato o museu não funciona como tal, não existe visitação pública, pois não há horário de abertura, algo muito óbvio a qualquer museu, e com isso ou por causa disso não há funcionário que recepcione o visitante espontâneo. Os atendimentos são eventuais, agendados por pesquisadores. Há no local, entretanto, uma exposição com objetos históricos junto com experimentos de demonstração contemporâneos sobre uma mesa central (com algumas identificações) e um modelo de demonstração do processo de geração de energia elétrica, rodeados por painéis gráficos (ilustrações, fotos e textos), com muitas informações genéricas, tais como "A história da energia" e "As usinas hidrelétricas e a utilização comercial da energia no Brasil", obviamente recortes de interesse, mas inoportunos, considerando que o patrimônio que deveria ser explicitado é o local, presente nos painéis, mas com menos ênfase. Junto a uma das paredes está o antigo painel de controle, peça em mármore de Carrara e bronze em estilo Art Nouveau, cujo relógio central na sua parte superior rodeado por elementos decorativos é atual e promocional da CPFL, o que destoa da bela peça histórica, assim como há tantos outros elementos não favoráveis que não mencionaremos. Em suma, houve uma intenção em realizar o que se entendeu como museu - uma exposição - e há uma desatenção na forma como este se encontra - fechado e inativo. 0 fato é que musealizar é mais do que um projeto e evento comemorativo, requer recuperação, conservação, documentação, pesquisa e comunicação de acervo, incluindo nesse conjunto curatorial a visitação pública sistematicamente organizada.

Com relação à Usina Elevatória da Traição, podemos dizer que a cidade de São Paulo passa por essa Usina. Se tomarmos a Usina como ponto central, podemos por meio dela ver o crescimento da cidade de São Paulo, seus fluxos de (intenso) trânsito, sua história, o entendimento do rio como elemento ambiental, o adensamento populacional, o fator econômico que predomina, vistos os enormes edifícios que a rodeiam, dentre outros aspectos da maior metrópole brasileira e terceira do planeta. A Usina, entretanto, nos informa sobre mais aspectos, dentre os mencionados. Se a cidade passa por ela, passa por ela todo o lixo produzido, a materialidade dos resíduos descartados, a poluição do rio Pinheiros, do ar e sonora. Temos a discutir que tipo de descarte, o que entendemos por lixo e poluição e que formas de sociabilidade estão implicadas. $O$ fato é, tudo o que a cidade não quer, joga no rio e esse tudo passa pela Traição.

A Usina Traição está encravada na cidade de São Paulo e tem muito a dizer sobre ela. É sobre essa particularidade que a Usina pode problematizar São Paulo. Nesse sentido, a problemática e o caráter educacional da Usina, em termos de musealização, é São Paulo e seus rios, São Paulo e seu lixo, a industrialização de São Paulo e seus subprodutos "invisíveis", porque se desejam esconder. A musealização da usina Traição compreenderia as instalações existentes, o rio, o entorno, a cidade. Como modelo de instituição, podemos sugerir "museu de cidade" a partir de um ponto de visão, pois cabe a este a cidade como problemática. Por esse modelo institucional seria possível organizar um circuito de visitação e sinalização adequada, montar exposições nos espaços da Usina e além dela (na ciclovia adjacente, por exemplo, e exposições itinerantes) e elaborar um programa de educação museal baseado na interdisciplinaridade que o objeto permite e exige, considerando as mais diversas faixas etárias. Outro modelo museal que podemos associar seria "museu de trajetos", pois esta Usina se interliga a outras, ampliando as questões possíveis na musealização.

\section{Considerações finais}

No Brasil precisamos equacionar a questão da preservação do patrimônio industrial e, nesse universo, a preservação do setor elétrico. Nesse imenso trabalho, a musealização deve ter a sua participação. A legislação e as políticas públicas devem ainda a sua contribuição, seja na preservação e fomento aos museus, mas sobretudo na disseminação da importância desse patrimônio para as construções identitárias e de memórias locais, regionais ou nacionais. Mas, a participação de setores públicos, acadêmicos e empresariais também se faz necessária, assim como a sociedade civil organizada em

CURY, M.X.; YAGUI, M.M.P. A musealização do setor elétrico em São Paulo: construção de perspectivas para as 
associações que levam a um desenvolvimento econômico, turístico e educacional local por meio do patrimônio industrial e elétrico.

Os dados coletados pelo eixo Musealização do projeto Eletromemória são reveladores. Os museus nas cercanias das usinas alvo do projeto não musealizaram, até o momento, esse patrimônio local e estadual. Como constatamos, poucas são as iniciativas e estas superficiais ainda. Há que se incentivar que parte da materialidade e documentalidade das usinas estejam sob a ação dos museus, sejam os museus de cidade, de ciência e tecnologia (também considerando os centros de ciências), de energia, de empresa, industrial ou arqueológico, de natureza administrativa municipal, estadual, privada, mista ou universitária. Vimos na ideia de museu e do patrimônio industrial "fora da fábrica" uma importante função, também no caso das usinas hidrelétricas. Como sugere Menezes, sair da "monumentalidade" presente in situ (nas usinas hidrelétricas, da arquitetura e engenharia, da paisagem, do maquinário, do território etc.) pode colaborar para outros aspectos da conservação e da comunicação do patrimônio do setor elétrico. Outros temas e abordagens poderiam, assim, ser tratados e discutidos com o público visitante, outros olhares poderiam ser afinados, outras percepções patrimoniais poderiam ser desenvolvidas e outras narrativas, inclusive e principalmente as autonarrativas dos (ex) funcionários e suas famílias, que poderiam ser agregadas ao discurso museal e ao patrimônio industrial do setor elétrico.

Quanto aos novos modelos museais, a filosofia do Museu de Salto - um núcleo central e diversos outras adjacentes a ele, e uma circulação conceitual designada como expografia no modelo museupercurso - (ROSSI; BARBUY, 1992) e o ideário do "museu descentralizado" da Eletropaulo, década de 1990 - conexões físico-patrimoniais com uma centralidade para orientações e logística - (DINIZ; TRÓIA; FERREIRA, 1990) demonstram serem boas estratégias. Essas duas iniciativas são estimulantes até o momento, assim como a Rede Museu da Energia, com sua sinergia em termos de conjugação entre PCH, entenda-se, museu in situ, e museus em edificações vinculadas ao processo industrial elétrico, com coleções e exposições. Diga-se, temos aqui um diálogo entre o modelo museu e o novo museu, agora com suas atualizações e possibilidades que contrariam a negação do museu pelo novo museu (DUARTE, 2013). Outro aspecto que ambas experiências nos sugerem é quanto à gestão museal para esses novos modelos, ora em percurso, ora em rede e/ou descentralizado. Quais seriam os melhores modelos de gestão para esses tipos e museus? Como associar gestão e sustentabilidade? Quais parcerias entre setores públicos, privados, acadêmicos e civis seriam necessárias? Como o empreendedor poderia receber as vantagens de um processo de musealização?

Quanto ao exercício de musealização que nos propomos a fazer, os dados são significativos, mas abrangentes. Levantamos alguns tópicos para melhor explicitá-los em forma de questionamentos:

- Quais são as oportunidades do cidadão paulista de refletir sobre a coleção hídrica do estado se não por um museu? Como um museu pode e deve trabalhar com essa conscientização cada vez mais premente?

- Como um museu pode trabalhar a ideia de território pelas usinas hidrelétricas?

- Como as usinas podem se associar a museus para preservação de parte do patrimônio industrial fora delas? Como compor um sistema de museus ou um museu em sistema (rede) que abraçasse a musealização do patrimônio do setor elétrico?

- As vilas operárias ainda são passíveis de restauração e uso para a musealização e a musealização seria uma possibilidade viável para sua preservação. Mas, nos indagamos onde estão as pessoas que lá viveram? O que pensam sobre o trabalho, a vida, a convivência e cultura do lugar e outras questões pertinentes à usina?

- Como se daria a participação dos funcionários e ex-funcionários na musealização das usinas? Quais os limites que a empresa traria e quais as potencialidades de participação?

- Como adequar as usinas hidrelétricas para a acessibilidade de pessoas com problemas de locomoção e com problemas visuais? Esse acesso é possível? Quais seriam as dificultadas e limites?

- Com a musealização de usinas hidrelétricas, como traçar um mapa cognitivo de temas para a pesquisa e a comunicação? Como estabelecer e comunicar os elos entre usina e 
urbanização?

- Como compor um programa e uma programação de visitação sem interferir negativamente no funcionamento da usina? Quais seriam os espaços destinados ao público e quais seriam e como seria a restrição de acesso a áreas restritas?

Uma ação de musealização do patrimônio do setor elétrico, in situ ou não, não pode prescindir de inúmeros profissionais e visões de áreas de conhecimento, para permitir as complexas interpretações inerentes ao patrimônio do setor elétrico. A metodologia interdisciplinar é inerente ao processo de musealização. Mas, também e igualmente relevante é o entendimento de que realizar museu requer projeto elaborado em equipe, planejamento e, sobretudo, considerar as especializações inerentes ao processo e nível compatível de profissionalização.

Será pois necessário esperar os reflexos introduzidos pelas novas práticas museológicas para que a máquina industrial seja reposicionada no seu valor e significado e o papel do operário, do patrão, da família, e de seus múltiplos contextos sociais e culturais sejam enfatizados dentro do espaço museológico e os museus industriais possam desta forma cumprir o seu papel essencial, o de promover as identidades das comunidades através daquele que é o seu saber e o seu saber fazer (MENEZES, 2006, p. 50).

Mas, isso tudo e muito mais só será possível com a base material que constitui o museu preservada: o patrimônio industrial.

\section{Referências}

ALCÂNTARA, Aureli Alves de. Paulo Duarte entre sítios e trincheiras em defesa da sua dama - a préhistória. 2007. Dissertação (Mestrado em Arqueologia) - Museu de Arqueologia e Etnologia, Universidade de São Paulo.

BARBOSA, Andréia Arruda. O Lugar da Memória Institucional nas Organizações Complexas. In: Congresso Brasileiro de Ciências da Comunicação, 35, 2012, Fortaleza. Anais... Fortaleza: Intercom, 2012.

Disponível em: <http://portal.eusoufamecos.net/o-lugar-da-memoria-institucional-nas-organizacoescomplexas/. Acesso em: 05 mai. 2014.

BLOISE, Ana Silvia. Museu da Energia: uma utopia torna-se realidade. Memória e energia, São Paulo, n. 27, p. 80-91, dez., 2000.

BRULON, Bruno. Os mitos do ecomuseu: entre representação e a realidade dos museus comunitários.

Revista Musas, n. 6, p. 30-47, 2014.

CURY, Marília Xavier. Museu, comunicação e exposição - o que há de novo? In: FRONTEIRAS REGIONAIS E PERSPECTIVAS NACIONAIS - Seminário Interdisciplinar em Museologia. Blumenau: Museu Hering: Fundação Hermann Hering, p. 35-49, 2014.

CURY, Marília Xavier Cury. Estudo sobre centros e museus de ciências - Subsídios para uma política de apoio. São Paulo: Vitae - Apoio à cultura, educação e promoção social, 2000.

DESVALLÉES, André. Cent quarante termes muséologiques ou petit glossaire de l'exposition. In: BARY, Marie-Odile \& TOBELEM, Jean-Michel (dir.). Manuel de muséographie: petit guide à l'usage des responsables de musée. Haute-Loire: Séguier/Option Culture, 1998.

DESVALLÉES, André; MAIRESSE, François (Org). Dictionnaire encyclopédique de muséologie. Paris: Armand Colin, 2011.

DINIZ, Renato; TRÓIA, Rosane; FERREIRA, Tânia C. Museu descentralizado. Memória, n. 9, p.51-56, out./ nov./dez. 1990. 
DUARTE, Alice. Nova museologia: os pontapés de saída de uma abordagem ainda inovadora. Revista Museologia e Patrimônio, v. 6, n. 1, 2013.

GRANATO, Marcus; MAIA, Elias da Silva; SANTOS, Fernanda Pires; OLIVEIRA, Pedro Louvain de campos; SANTOS, Liliane Bispo dos; HANDFAS, Ethel Rosemberg. Valorização do patrimônio científico e tecnológico brasileiro: resultados de pesquisa. XIV Encontro Nacional de Pesquisa em Ciência da Informação (Enancib), 2013. p. 1-20.

GUARNIERI, Waldisa Russio Camargo. L'interdisciplinarité en Muséologie. MuWop/DoTraM, Estocolmo: ICOM, n. 2, 1981, p. 58-59.

GUARNIERI, Waldisa Russio. Um museu de indústria em São Paulo. 1980. (Tese) - Escola de Sociologia e Política de São Paulo, São Paulo, 1980.

HANDFAS, Ethel Rosemberg; VALENTE, Maria Esther Alvarez. Políticas públicas de C\&T e os museus de ciência. XIV Encontro Nacional de Pesquisa em Ciência da Informação (Enancib), 2013. p. 1-19.

INSTITUTO BRASILEIRO DE MUSEUS (IBRAM). Guia dos museus brasileiros. Brasília, 2011.

INSTITUTO DO PATRIMÔNIO HISTÓRICO E ARTÍSTICO NACIONAL (IPHAN). Disponível em: http:// portal.iphan.gov.br/portal/baixaFcdAnexo.do?id=3263.

LIMA, Diana Farjalla Correia. Musealização e patrimonialização: formas culturais integradas, termos e conceitos entrelaçados. In: ENCONTRO NACIONAL DE PESQUISA EM CIÊNCIA DA INFORMAÇÃO, 15, 2014, Belo Horizonte. Anais... Belo Horizonte: Enancib 2014. p. 3710-3730.

LIMA, Diana Farjalla Correia. Da face inativa da indústria ao contexto ativo do museu: aspectos da musealização do patrimônio industrial. In: ENCONTRO NACIONAL DE PESQUISA EM CIÊNCIA DA INFORMAÇÃO, 14, 2013, Florianópolis. Anais... Florianópolis: Enancib 2013. Disponível em: http:// enancib.sites.ufsc.br/index.php/enancib2013/XIVenancib/paper/viewFile/221/393.

MATOS, Ana Cardoso; SAMPAIO, Maria da Luz. Patrimônio Industrial e museologia em Portugal. Museologia e Interdisciplinaridade, v. 3, n. 5, p. 95-112, mai./jun. 2014.

MENEZES, Susana. Do museu e da museologia. Cadernos de Sociomuseologia, n. 26, p. 19-50, 2006.

MORAIS. José Luiz. Reflexões acerca da arqueologia preventiva. In: MORI, V. H.; SOUZA, M. C.; BASTOS, R. L.; GALLO, H. (Orgs.). Patrimônio: atualizando o debate. São Paulo: IPHAN, 2006. p. 193-220.

MORTATI, Débora Marques de Almeida Nogueira; ARGOLLO FERRÃO, André Munhoz de. Centrais hidrelétricas: o surgimento das usinas hidrelétricas e seu papel na urbanização do interior do estado de São Paulo, Brasil. Revista Llámpara: patrimonio industrial, Valladolid, v. 5, p. 68-77, 2012. Disponível em: http://issuu.com/cdmdsn/docs/revista5ok.

QUEIROZ, Inti Anny. As leis de incentivo à cultura em São Paulo: panorama estadual e municipal. Revista Pensamento \& Realidade, ano XVI, v. 28, n 4/2013, p. 106-119, 2013. Disponível em: <http:// revistas.pucsp.br/index.php/pensamentorealidade/article/view/17985>. Acesso em: 19 jan. 2015.

RODRIGUES, José Eduardo Ramos. Da proteção jurídica ao patrimônio cultural arqueológico. In: MORI, V. H.; SOUZA, M. C.; BASTOS, R. L.; GALLO, H. (Orgs.). Patrimônio: atualizando o debate. São Paulo: IPHAN, 2006. p. 234-240.

ROSSI, Anicleide Zequini; BARBUY, Heloisa. Museu da cidade de Salto: projeto e implantação. Boletim do Centro de Memória UNICAMP, v. 4, n. 7/8, p. 53-64, jan./dez.1992. 
SANTOS, Myrian Sepulveda dos. Museus, liberalismo e indústria cultural. Ciências Sociais Unisinos, v. 47, n. 3, p. 189-198, set./dez. 2011.

SÃO PAULO (estado). Lei 12.268 de 20 de fevereiro de 2006. Institui o Programa de Ação cultural - PAC, e dá providências correlatas. LEI ICMS-SP. Disponível em: <http://www.cultura.sp.gov.br/StaticFiles/SEC/ proac/LEGISLACAO\%20marco\%2010.pdf>. Acesso em 19 de janeiro de 2015.

SCHEINER, Tereza Cristina. Repensando o museu integral: do conceito às práticas. Boletim do Museu Paraense Emílio Goeldi. Ciências Humanas, v. 7, n. 1, p. 15-30, jan./abr. 2012.

SILVA, Carlos Henrique Gomes da; PINHEIRO, Lena Vania Ribeiro. Políticas públicas para museus no Brasil: do Iphan ao Ibram. XIV Encontro Nacional de Pesquisa em Ciência da Informação (Enancib), 2013. p. 1-20.

SISTEMA ESTADUAL DE MUSEUS. Museus SP. Disponível em: <http://www.sisemsp.org.br/index.php? option=com_content\&view=article\&id=1004\&Itemid=69>. Acesso em: 19 jan. 2015.

SOUSA, Sara Barbosa de. Memória Empresarial: interesse utilitarista ou responsabilidade histórica? 2010. 130f. Dissertação (Mestrado em Ciência da Informação) - Escola de Comunicações e Artes, Universidade de São Paulo, São Paulo, 2010. Disponível em <http://www.teses.usp.br/teses/disponiveis/ 27/27151/ tde...131012/.../2200998.pdf>. Acesso em: 05 mai. 2014.

TOTINI, Beth; GAGETE, Élida. Memória empresarial, uma análise da sua evolução. P. 113-126. In: Memória de empresa: história e comunicação de mãos dadas a construir o futuro das organizações. São Paulo: Aberje editorial, 2004.

YAGUI, Mirian Midori Peres. Museus e patrimônio industrial: um estudo sobre a musealização do setor elétrico no estado de São Paulo. 2014. 172f. Dissertação (Mestrado em Museologia) - Pósgraduação Interunidades em Museologia, Universidade de São Paulo, São Paulo, 2014.

ZANETTINI ARQUEOLOGIA. Disponível em: http://www.zanettiniarqueologia.com.br/index.php. Acesso: 24 de jan 2015. 